\title{
The Remains of the Fray: Nascent Colonialism and Heterogeneous Hybridity
}

\author{
Charles R. Cobb (iD, James B. Legg, Steven D. Smith, Chester B. DePratter, Brad R. Lieb, \\ and Edmond A. Boudreaux III
}

\begin{abstract}
Investigations at the Native American site complex of Stark Farms in Mississippi, USA, have yielded numerous examples of metal artifacts of European origin. Our study suggests that they derive from contact between the AD 1540-1541 winter encampment of the Spanish Hernando de Soto expedition and the local Indigenous polity. The artifacts display a wide range of modifications, uses, and depositional contexts congruent with hybrid practices. We argue that the early colonial setting of Stark Farms requires a different perspective on cultural mixing than is often applied in studies of European colonialism. This is highlighted by the strongly improvisational nature of the modification of the metal objects, embodying a political climate in which European incursions were precarious and in which hybridity and power were heterogeneous and fluid.
\end{abstract}

Keywords: hybridity, colonial encounters, Chikasha, Hernando de Soto, conflict

Las investigaciones en el complejo arqueológico nativo norteamericano de Stark Farms en Mississippi (EE. UU) han brindado una amplia colección de artefactos metálicos de origen europeo. Nuestro estudio sugiere que provienen del contacto que ocurrió en 1540-1541 dC entre el campamento de invierno de la expedición española de Hernando de Soto y la comunidad indígena local. Los artefactos demuestran una gran variedad de modificaciones, usos y contextos deposicionales congruentes con prácticas híbridas. Argumentamos que el contexto colonial temprano de Stark Farms requiere una perspectiva diferente sobre las mezclas culturales a la que se aplica a menudo a los estudios sobre el colonialismo europeo. Esto se observa particularmente por el carácter muy improvisado de las modificaciones hechas en los objetos, que ilustran un clima político donde las incursiones europeas eran precarias, mientras hibridad y poder eran heterogéneos y fluidos.

Palabras clave: hibridación, encuentros coloniales, Chikasha, Hernando de Soto, conflicto

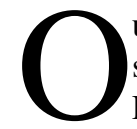

ur research on a cluster of sites in Mississippi, USA, known collectively as Stark Farms, has yielded a distinctive assemblage of metal artifacts ${ }^{1}$ likely linked to Hernando de Soto's sixteenth-century expedition (1539-1543) in southeastern North America (hereafter, Southeast; Figure 1). In our studies, we have faced a conundrum of how best to conceptualize and interpret these objects, many of which were modified by Native Americans. Given the swirling debates over hybridity and related concepts, how do we best fill in the blank for the process by which horseshoe fragments became scrapers, barrel bands became celts, and copper-alloy fragments became tubular beads? Was it hybridity? Creolization?

Charles R. Cobb (ccobb@ flmnh.ufl.edu, corresponding author) — Florida Museum of Natural History, 1659 Museum Road, University of Florida, Gainesville, FL 32611, USA

James B. Legg, Steven D. Smith, and Chester B. DePratter $\square$ South Carolina Institute of Archaeology and Anthropology, 1321 Pendleton Street, University of South Carolina, Columbia, SC 29208, USA

Brad R. Lieb $\mathbf{~ H e r i t a g e ~ P r e s e r v a t i o n ~ D i v i s i o n , ~ D e p a r t m e n t ~ o f ~ C u l t u r e ~ a n d ~ H u m a n i t i e s , ~ C h i c k a s a w ~ N a t i o n , ~ P O ~ B o x ~ 1 5 4 8 , ~}$ Ada, OK 74821, USA

Edmond A. Boudreaux III $\square$ Department of Sociology and Anthropology, 615 Grove Loop, 565 Lamar Hall, University of Mississippi, University, MS 38677, USA

American Antiquity 86(3), 2021, pp. 569-592

Copyright $($ ) The Author(s), 2021. Published by Cambridge University Press on behalf of the Society for American Archaeology. This is an Open Access article, distributed under the terms of the Creative Commons Attribution licence (http://creativecommons.org/licenses/by/4.0/), which permits unrestricted re-use, distribution, and reproduction in any medium, provided the original work is properly cited. doi:10.1017/aaq.2021.17 


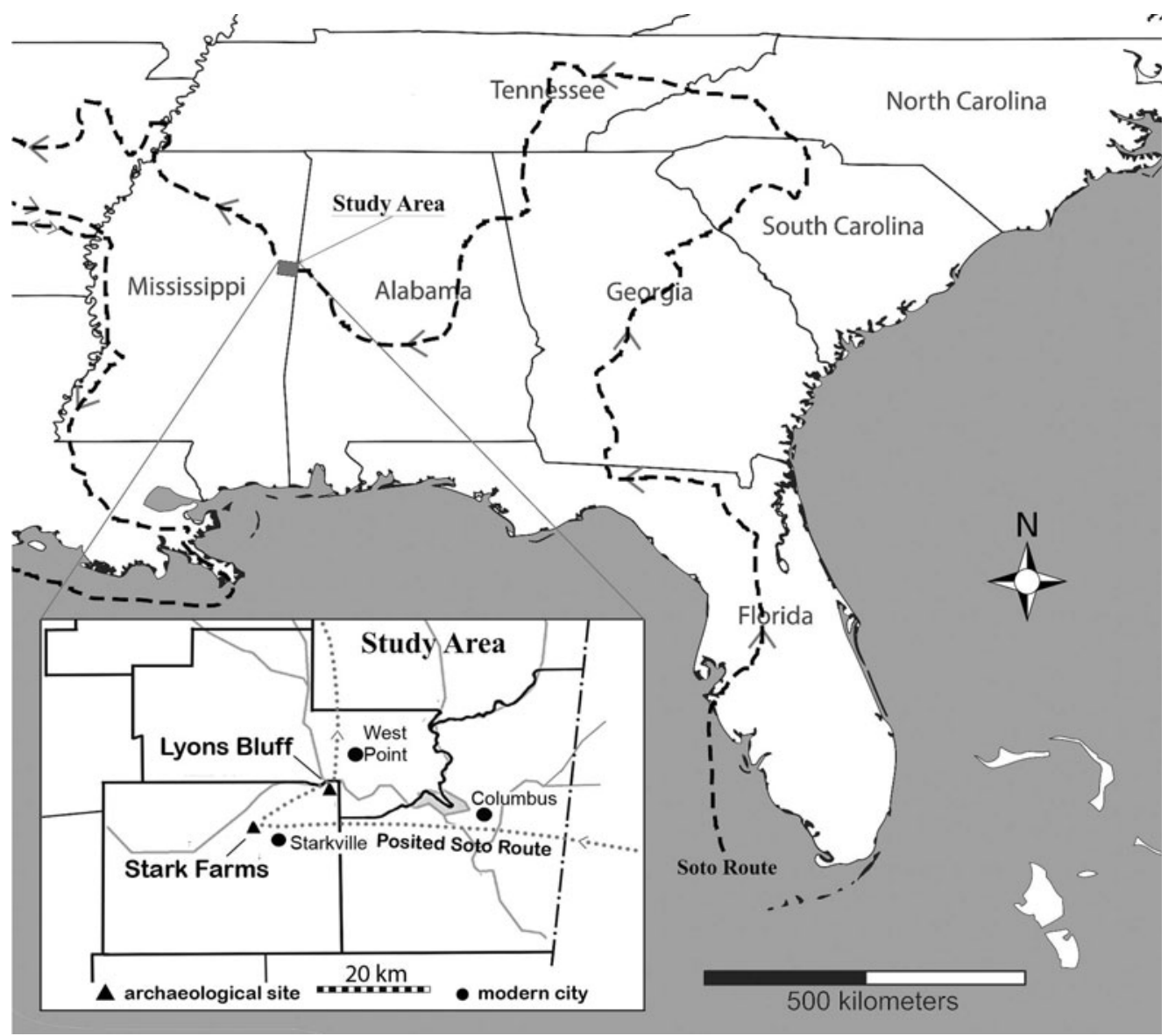

Figure 1. Stark Farms vicinity (inset) and projected route of Soto, 1540-1541 (prepared by Timothy D. Pieper, South Carolina Institute of Archaeology and Anthropology).

Entanglement? Does it matter what we call it? By adopting a specific term for the material melding of different cultural traditions, have we taken a stake in a theoretical perspective, opening some avenues for interpretation while closing others?

The assessments of hybridity and related concepts are varied, and there are several useful reviews in the literature (e.g., Card 2013; Liebmann 2015; Palmié 2013; Silliman 2013, 2015; VanValkenburgh 2013; Werbner 1997). Although the caveats are wide ranging, in condensed form, three interrelated strands have emerged that seem to be of particular significance to our study: ontology, epistemology, and history. First, the ontological inquiry reflects a concern with a priori assumptions about the purity of objects, assemblages, or social entities before they came together as putative hybrids (Palmié 2013; Stockhammer 2013:13; VanValkenburgh 2013:306). Following this critique, cultures are always engaged in a dynamic churn of borrowing and innovation; by definition they are hybrid (Bakhtin 1981; Bhaba 1994; Latour 1991; Palmié 2013:468). Consequently, to define something as hybrid because it seems to embody two or more distinct traditions is to create boundary conditions that are just as likely to be a function of observer bias as they are a classification imposed by those who created or used the hybrid. As Palmié (2013) asks, where (and why) do we make the cut?

Second, these points are interwoven with debates over the relative theoretical merits and drawbacks of hybridity versus alternative concepts. "Entanglement" has gained favor in recent years because its advocates argue that it is less 
prone to the failings of essentialism and biological metaphors (cf. Jordan 2014; Silliman 2016; Stockhammer 2013). Some proponents of hybridity have found "entanglement" unsatisfactory because, they argue, the term is denatured of a connection to the relations of inequality that frame colonialism (Liebmann 2013; Silliman 2015). A similar charge has been leveled against creolization (Mullins and Paynter 2000). These debates raise a fundamental issue: what do we really want to know when we highlight the hybrid characteristics of an object or an assemblage? The most consistent-and in our opinion, valid-support for addressing hybridity in colonial contexts is its linkage with relations of power (Liebmann 2015:322; Loren 2013; Silliman 2015:282). In other words, it seems to be a particularly compelling concept when it evokes "competing visions of reality and political struggles" between aspiring colonizers and those whom they aspire to colonize (VanValkenburgh 2013:312).

Our third point follows directly from the second. The larger spatiotemporal context of hybridity in the era of European colonialism mediates the ways in which belonging and power are phrased. Many of the seminal theoretical works on hybridity have been situated within an arena of advanced colonialism. This is a period when major cultural, political, and economic transformations had already been underway for at least one to two centuries and when colonial regimes were often well established, even if their dominance was problematic. But this interval represents only a slice of the colonial experience. The postcolonial engagement with the power subtleties of earlier forms of European expansion has been slight in comparison to the latter age of empires (Ehrhardt 2013:370; Voss 2011:15). Moreover, because the oft-cited luminaries of hybridity (e.g., Bakhtin 1981; Bhabha 1994; Latour 1991) largely draw their observations from contexts of late-European colonialism or globalization, the forms of hybridity they address are typically ubiquitous due to a longestablished, widespread circulation of goods, media, peoples, and ideas. As a result, they emphasize the theoretical dilemma of understanding how " $[\mathrm{h}]$ ybridity is celebrated as powerfully interruptive and yet theorized as commonplace and pervasive" (Werbner 1997:1). The conditions of early-European colonialism, however, often run counter to these two themes: it is a time when structures and institutions of domination were still embryonic, when relations of power were highly heterogeneous, when the geopolitical status of European incursions was precarious, and when material forms of cultural mixing may have been relatively novel. As ethnohistorians have demonstrated (e.g., DuVal 2006; White 1991), a number of Native American peoples in eastern North America exercised a considerable degree of autonomy and territorial control for centuries after the arrival of the first Europeans. The shifting power interactions between and among these groups confound generalizations about the nature of hybrid practices.

Our ensuing study emphasizes how historical context complicates the ontology and epistemology of cultural mixing and the methods employed to address it. Even if the concept of hybridity is narrowed down to an examination of relations of power, "colonial" is far too broad of a notion-socially, culturally, and temporally - for outlining a study. We must ask not only what a hybrid is but when a hybrid is: "Under what socially and historically specifiable conditions do any of them [hybrids] emerge, become ratified or contested, eventually normalized, suppressed, or transformed, with all the potential violence any of these options may imply?" (Palmié 2013:472). As we will argue, the acquisition, transformation, and use of objects of European origin in the 1500s to early 1600s in the interior American Southeast seem to have followed a distinct cultural trajectory of hybrid practices before European imperial projects began to make significant inroads in the region.

We note that we first published a descriptive analysis of a portion of the metal artifact assemblage (Legg et al. 2019) in a comparative study with the contemporary Glass site (Georgia) to demonstrate that mechanisms in addition to gifting may have been an important factor in the occurrence of metal objects on sixteenth-century Indigenous sites. In a more recent study (Legg et al. 2020), we provided a more thorough descriptive analysis of the assemblage and its 
context to make the argument that it was probably linked to the Hernando do Soto entrada. In this article, we provide our first theoretical and methodological assessment of the hybrid dimensions of the metal tools, alongside our argument for the necessity of situating the spatiotemporal context of hybrid practices.

\section{Situating Sixteenth-Century Colonialism in the American Southeast}

European colonialism was an ensemble of highly heterogenous projects and agendas. It changed dramatically over the course of time as evolving attitudes toward the Other, shifting geopolitical fortunes, ongoing philosophical changes (Renaissance to Enlightenment to post-Enlightenment), economic transformations (mercantilism to industrialism), and other trends all transformed the contours of colonial aspirations. In turn, the responses of Indigenous peoples to European encroachments, coupled with their own ambitions, profoundly shaped and reshaped the colonial terrain over the centuries. Furthermore, the variable spatial encroachments of colonialism led to a complicated mix of European and Indigenous peoples that was distinctive to any given locale, thereby making it difficult to extrapolate conditions from one region to another except in a very general way. Consequently, outlining a study in the context of European colonialism requires a number of qualifiers denoting time, region, and relevant peoples because these all factor into the calculus of the logic and effects of hybridity (Thomas 1994:48).

Debates in Native American literary criticism and cultural studies have taken up this issue, faulting postcolonial scholarship for failing to parse colonial histories more finely (Carpenter 2008; Rifkin 2017; Sexton 2016; Vizenor 1999; Weaver et al. 2006). This line of research has attempted to model the progression of European colonialism in two crosscutting ways: to emphasize that it qualitatively changed through time (even if in a time-transgressive manner globally) while at the same time recognizing that it was never a strictly linear nor totalizing enterprise. Mark Rifkin (2017), for example, distinguishes colonialism - the early stages of attempting to dominate Indigenous peoples- from settler colonialism, which is where colonials have occupied Indigenous landscapes and are actively working to remove both the presence and memory of their original inhabitants. But he recognizes that both can co-occur in the same region and even be articulated with one another. For his part, Gerald Vizenor (1999:109) relies on "paracolonialism" to characterize what is commonly referred to as advanced or settler colonialism. In contrast, the notion of "pericolonial" has been employed for an even more advanced and pervasive settler colonialism that, for Indigenous peoples, "must be "gotten around, under, or through" (Weaver et al. 2006:39). This kind of thinking has been condensing for some time among a number of archaeologists. They have called for demarcating settings where the ripples of European colonialism may have been present but where colonization had yet to be achieved either because it was in its formative stages or because Indigenous societies were successful at fending off European incursions (e.g., Bayman 2009; Cobb 2003; Ehrhardt 2013; Gosden 2004; Hauser et al. 2019; Jordan and Gerard-Little 2019; Silliman 2005).

Stephen Acabado (2017) addresses these circumstances within the Ifugao highlands at the onset of Spanish penetration in the northern Philippines in the eighteenth and early nineteenth centuries. He rephrases the notion of pericolonialism somewhat to describe regions such as this that may have been impacted by advanced colonial interactions or incursions in adjoining areas yet still remained relatively unfettered from the military and administrative dominance of a European colony. Whereas the adjoining coastal lowland region came under Spanish control, the archaeological record is suggestive of important transformations in the highlands in the absence of direct Spanish presence. These include the appearance of porcelain and stoneware ceramics, an increased abundance of pig and water buffalo, and the adoption of intensive rice-farming field techniques to produce larger surpluses. Acabado attributes these changes largely to trade opportunities introduced by Spanish enclaves in bordering areas, although the Spanish crown exerted minimal influence in the highlands. Sarah Trabert (2018) sees similar processes at work in the migration of a Puebloan group from 
northern New Mexico to western Kansas in the mid-1600s. Although Spanish encroachments in the Southwest propelled this move, the Puebloan peoples-once established in their new territory-appear to have been peacefully accommodated by the local Ndee peoples. Patterns of material hybridity are expressed in several ways, including the mingling of Pueblo and Ndee pottery technology and style traditions. For both cases, cultural mixing was prompted by relatively indirect forces of colonialism. Spanish activities may have influenced trade networks in the upland Philippines and propelled populations into western Kansas, but in neither case were Spaniards living within the respective localities and attempting to bend Indigenous peoples to their will.

At a time when colonization efforts in nearby Mexico and portions of the Caribbean were rapidly intensifying - that is, the AD sixteenth and seventeenth centuries - the American Southeast witnessed a highly uneven history of nascent and settler colonialism. The interior region in particular was only sporadically visited by Spanish explorers and hopeful colonizers in the 1500s. Then, it became relatively isolated again following European withdrawal from intensive efforts at settlement until the late 1600s. Rather than a steady arc of increasing colonial control, the first centuries of European forays were characterized by numerous advances and retreats as well as oscillating interactions between Indigenous groups and colonials. This checkered history under Spain began with the initial expedition of Ponce de León in 1513 , followed by a 50-year interval during which exploratory expeditions followed by settlement efforts large and small failed - sometimes disastrously — to build a permanent presence in the region. Two colonizing efforts by the French crown in the 1560s also miscarried. The establishment of St. Augustine in 1565 in peninsular Florida by Pedro Menéndez de Avilés represented the first successful effort to maintain a settlement. In sum, the colonial Southeast in the sixteenth century comprised a narrative of disentanglements (see Semerari 2017) as well as entanglements, nonlinearity as well as linearity (see Howey 2011). Histories of southeastern hybridity must be viewed in this flickering light.
Prior to the founding of St. Augustine, Hernando de Soto's 1539-1543 Southeast entrada stands as one of the most well-known Spanish forays in North America, one that has widely sparked popular imagination and drawn considerable scholarly interest. Archaeologists and historians have found the first- and secondhand accounts (Clayton et al. 1993)-despite the usual panoply of embellishments and biasesto be particularly important for depicting an impressive variety of Native American societies at "first contact." Soto and his entourage never established any permanent settlements, and their length of stay with Indigenous communities varied from brief overnight stops to winter encampments of several months' duration. Despite landing in the Tampa, Florida, region with a sizable (if steadily dwindling) force of over 600 individuals that eventually traveled west of the Mississippi River, secure archaeological signatures of any of their layovers have been frustratingly elusive. The first winter encampment (1539-1540) in present-day Tallahassee, Florida, represents the only site location that most archaeologists seem to agree can be attributed to Soto's party (Ewen and Hann 1998).

Our investigations over the past five years in northeastern Mississippi at several archaeological loci known collectively as Stark Farms have recovered a sizable assemblage of metal artifacts that we believe can be attributed in part to a violent encounter between the Soto expedition and a town referred to in the Spanish accounts as Chikasha (Legg et al. 2019). ${ }^{2}$ Chikasha was the location of the second winter encampment, which is where Soto had received permission from the leader of the surrounding polity to keep his troops in the eponymous primary town (December 1540-March 1541). He and his men soon fell into their predictable pattern of alienating their hosts through violence and constant demands for resources, precipitating a surprise attack by the Chikasha following Spanish demands for hundreds of burden bearers just before the expedition was due to depart in the spring. Soto's forces escaped, but only after a brief yet violent skirmish that left at least a dozen Europeans dead, a significant store of supplies captured or burned after the Chikashans set the town on fire, and scores of horses and pigs 
lost in the conflagration (Robertson 1993:107; Worth 1993a:297, 1993b:237).

Following the establishment of St. Augustine, much of the Spanish crown's efforts went into establishing an extensive mission system in the Florida peninsula and southeastern Georgia (McEwan 1993; Milanich 1999). Although there were occasional explorations into the interior in the $1600 \mathrm{~s}$, they were of greatly limited scope. This retrenchment led to a period of almost 150 years of relative documentary silence that has been referred to as "the forgotten centuries" (Hudson and Tesser 1994). Although Jamestown, Virginia, was settled by England in 1607, the few expeditions undertaken from there halted at the Appalachian Mountains. Renewed European interactions with the interior only surged when England founded Carolina in 1670 and France founded Louisiana in 1699, igniting a three-way competition to gain the favor of powerful Native American polities throughout the Southeast.

Prior to the renewed burst of colonizing enthusiasm in the late 1600s, Native American communities in the Southeast interior enjoyed a distant colonial relationship with European powers, primarily the Spanish colony of La Florida. Under these circumstances, there were a variety of ways by which Indigenous groups may have acquired objects of European origin. Smith and Hally (2020) postulate six such mechanisms: formal gifts from European explorers, barter, trophy-taking through battle, theft, scavenging, and shipwreck salvage. No matter how acquired, however, in sixteenth-century contexts, European objects often seem to have been highly valued: they usually occur in modest numbers at a site, display little to no modification, and are frequently interred in burials (Atkinson 1979; Hally 2008; Little 2008:44, 73; Mitchem 1989; Smith 1987:26-27). With only a few possible exceptions (e.g., Blanton 2020), not until well into the 1600 s did such objects begin to find a place in the communities of Native Americans on a regular basis.

\section{Archaeology at Stark Farms}

In 2015, the Chickasaw Nation conceived a longterm project with the dual goals of identifying ancestral sites in their traditional territory in northern Mississippi and providing Chickasaw college students an opportunity to reconnect with their cultural heritage through collaborative archaeological fieldwork experiences in the Chickasaw Explorers Program (Thomas 2017). ${ }^{3}$ The Stark Farms cluster (Figure 2), documented in a cultural resource management shovel-test survey in 2014, seemed particularly promising because it had yielded ceramic types broadly dating to the European contact era-or AD 1400s-1600s -although no metal artifacts had been recovered (RabbySmith et al. 2015). Archaeological investigations suggest that Stark Farms represents a dispersed town or loosely aggregated house groups spread across a substantial upland prairie ridge system. With the onset of our metal detector survey in 2015 at the largest of the Stark Farms sites, 22OK778, we almost immediately discovered iron celts, reworked Biscayanstyle axes, rolled sheet copper-alloy beads, and other metal artifacts (Legg et al. 2019). These finds instigated five seasons (2015-2019) of fieldwork at Stark Farms, with the Chickasaw Nation leading a consortium consisting of the Universities of Mississippi, South Carolina, and Florida. Block excavations in feature-rich locations were complemented by $100 \%$ metaldetector survey coverage in core site areas of Stark Farms (Figure 3). The survey consisted of archaeologists detecting in marked blocks along overlapping transects, approximately 1.5 $\mathrm{m}$ wide. Over repeated seasons, many blocks were resurveyed multiple times, especially the heart of 22OK778. Point proveniences were recorded for all premodern metal objects. In addition, we conducted reconnaissance metal detector surveys on surrounding landforms and at previously recorded, outlying sites suspected to date to the same time period. Except for the Ramsey site, located just to the west of the Stark Farms complex (Figure 3), these forays did not recover any early-European metal objects.

Our research has revealed that, in many respects, Stark Farms sites are typical of late pre-European-contact to contact period sites located in the Blackland Prairie - an arc of agriculturally rich, upland prairie running across Mississippi and Alabama. These sites were 


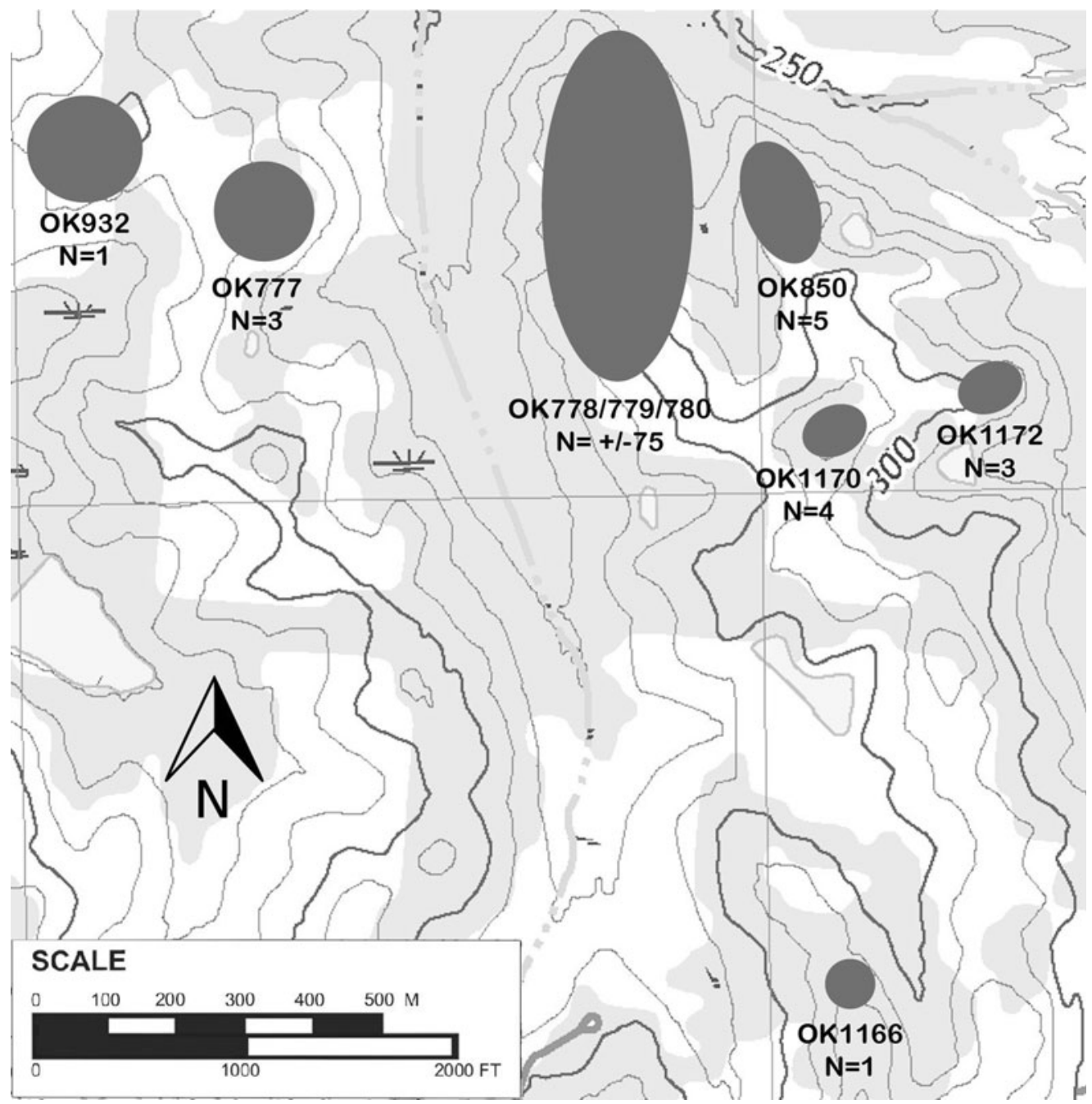

Figure 2. Stark Farms complex, showing sites positive for metal artifacts and quantities by site (U.S. Geological Survey, USGS quadrangle 7.5-minute map for Starkville, MS 2018).

dispersed hamlets and towns strongly reliant on maize agriculture, where residents inhabited round-to-apsidal single-set-post structures. Signatures of social hierarchy through mortuary interments are slight. Although these settlements seem to be related to the Mississippian phenomenon, with the exception of the Lyons Bluff site about $15 \mathrm{~km}$ east of Stark Farms, there is no evidence of the aggregated towns with earthen platform mounds that are typical of contemporary sites in the nearby Tombigbee River Valley about $40 \mathrm{~km}$ to the east (Blitz 1993). If not for the Soto accounts describing a number of sizable polities in the prairie region, archaeologists would be hard put to identify political entities such as Chikasha based on traditional material correlates. An unusually dense cluster of fifteenthto seventeenth-century sites (including Stark Farms) known as the Starkville Archaeological Complex (SAC) is found in the locality of the modern city of Starkville (Clark 2017). There have been documented cases of early-European materials recovered in mortuary contexts in sites in the Rolling Hills vicinity of the SAC (see Figure 3), but these are very rare (Atkinson 1979). Very few SAC sites have been excavated and reported in detail (e.g., Hogue and Peacock 1995; Peacock 1995; Rafferty 2001; Rafferty and Hogue 1999). 


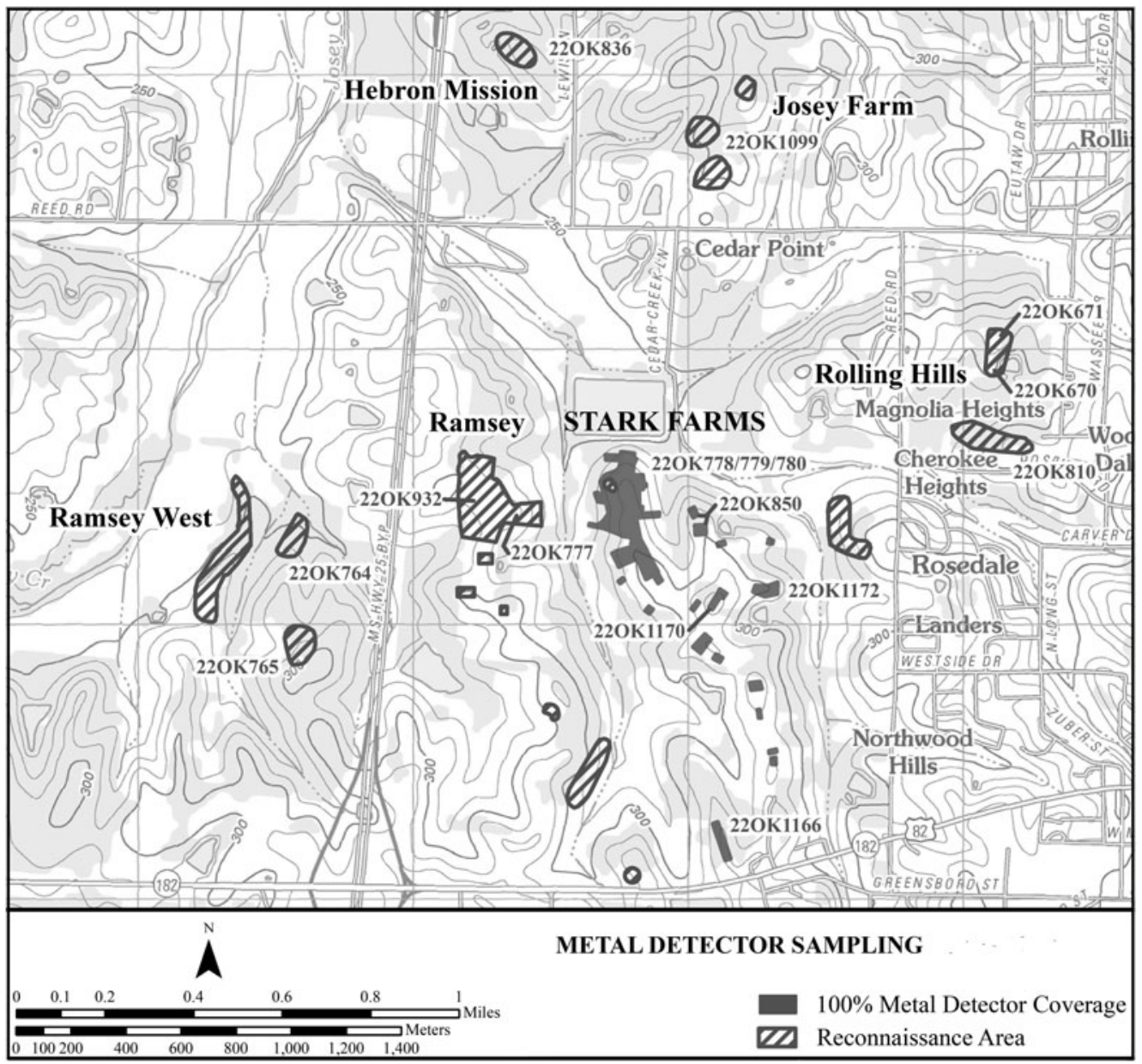

Figure 3. Metal detector coverage at Stark Farms and outlying sites (prepared by Tamara S. Wilson, South Carolina Institute of Archaeology and Anthropology; U.S. Geological Survey, USGS quadrangle 7.5-minute map for Starkville, MS 2018).

As a result, the notion of a "complex" is still a poorly understood catchall for Mississippian through contact period sites in the area, and it is difficult to place Stark Farms within a local or regional comparative framework.

Nevertheless, site 220K778 does bear a distinctive imprint for the region (Boudreaux et al. 2020). It is larger than most contemporary sites in the area, and it contains the bulk of the recovered metal artifacts. Furthermore, the ridgetop that is the core of the site has an unusually dense welter of posts that speaks to considerable building activity. Within one large, single-setpost structure, we have identified a prepared, cross-shaped clay hearth embodying four-corner, sacred fire symbolism, leading us to suspect that this was a central public building. Several daub pits on the site-large borrow pits where clay was removed for building construction-contained rich assemblages of flora, fauna, ceramics, and lithics. The AMS dates for Starks Farms, along with the ceramic types, support an occupation from the 1300s to mid-1600s (Boudreaux et al. 2020; Clark 2017; Johnson 1996). Unfortunately, the radiocarbon curve for the sixteenth century has multiple intercepts, so it is not possible to confirm mid-sixteenth-century contexts via chronometric methods.

Systematic metal detector coverage across the Stark Farms sites has yielded at least 83 metal artifacts that seem to be of sixteenth-century European vintage (Table 1). ${ }^{4}$ It should be 
Table 1. Objects of European Origin from the Stark Farms Site.

\begin{tabular}{|c|c|c|c|c|}
\hline Category & Identification & Comments & $\begin{array}{l}\text { Raw } \\
\text { Material }\end{array}$ & Provenience \\
\hline \multirow[t]{17}{*}{ Unmodified } & Lead shot & $0.575^{\prime \prime}$ caliber, fired & lead & $22 \mathrm{OK} 777-3$ \\
\hline & Lead shot & $0.577^{\prime \prime}$ caliber (est.), melted & lead & $22 \mathrm{OK} 777-8$ \\
\hline & Lead shot & $0.550^{\prime \prime}$ caliber & lead & $22 \mathrm{OK} 1172-2$ \\
\hline & Nail & wrought iron, broken tip & iron & $22 \mathrm{OK} 778-25$ \\
\hline & Nail & wrought iron, broken tip & iron & 22OK850-1 \\
\hline & Nail & wrought iron & iron & $22 \mathrm{OK} 1170-7$ \\
\hline & Nail shaft & wrought iron & iron & $22 \mathrm{OK}-112$ \\
\hline & Mouth harp & $\begin{array}{l}\text { consistent with both sixteenth- and } \\
\text { eighteenth-century types }\end{array}$ & iron & 22OK778-39 \\
\hline & $\begin{array}{r}\text { Barrel band } \\
\text { fragment }\end{array}$ & unmodified & iron & $22 \mathrm{OK} 778-54$ \\
\hline & Harness ring (?) & crudely forged; possibly replacement harness ring & iron & $22 \mathrm{OK} 778-15$ \\
\hline & Harness ring (?) & flattened wrought-iron rod stock & iron & IF001, 2-2019 \\
\hline & Harness ring (?) & wrought-iron round stock & iron & IF002, 2-2019 \\
\hline & Ramrod tip & interior wood intact & copper alloy & $22 \mathrm{OK} 778-84$ \\
\hline & Iron shot & $32 \mathrm{~mm}$ diameter, faint mold seam & cast iron & 22OK778-99 \\
\hline & Hook & & iron & $22 \mathrm{OK} 778-111$ \\
\hline & $\begin{array}{l}\text { Unidentified } \\
\text { vessel }\end{array}$ & $\begin{array}{l}\text { wrought and sheet-metal fragments, attached with } \\
\text { rivets }\end{array}$ & iron & 22OK778-86 \\
\hline & Boss/escutcheon & brass plate with lead fill; gold leaf cross & brass/lead & IF003, 10-2019 \\
\hline \multirow[t]{23}{*}{$\begin{array}{l}\text { Modified } \\
\text { Utilitarian }\end{array}$} & Cutting tool & $\begin{array}{l}\text { flat fragment: one bifacially ground edge; the other } \\
\text { edge ground flat }\end{array}$ & iron & $22 \mathrm{OK} 778-80$ \\
\hline & Cutting tool & auger bit with tip reduced to a point & iron & $22 \mathrm{OK} 778-106$ \\
\hline & Cutting tool & axe head, nearly exhausted from resharpening & iron & $22 \mathrm{OK} 850-2$ \\
\hline & Scraping tool (?) & sheet metal: sharply ground edge & copper alloy & $22 \mathrm{OK} 778-28$ \\
\hline & Celt & horseshoe fragment & iron & 22OK778-19 \\
\hline & Celt & axe fragment & iron & 22OK778-20 \\
\hline & Celt & axe fragment & iron & $22 \mathrm{OK} 778-26$ \\
\hline & Celt & axe fragment & iron & $22 \mathrm{OK} 1172-4$ \\
\hline & Celt & axe fragment & iron & $22 \mathrm{OK} 778-30$ \\
\hline & Celt & possible axe-blade fragment & iron & 22OK778-94 \\
\hline & Celt & possible sword fragment & iron & $22 \mathrm{OK} 778-114$ \\
\hline & Celt or adze & unidentified stock & iron & 22OK777-9 \\
\hline & Celt or scraper & unidentified stock & iron & 22OK778-59 \\
\hline & Chisel & upper portion of wrought nail flattened to bifacial bit & iron & 22OK778-90 \\
\hline & $\begin{array}{l}\text { Knife blade } \\
\text { (partial) }\end{array}$ & broken end of blade neatly ground & iron & 22OK778-51 \\
\hline & Knife blade (?) & bifacially sharpened edges & iron & $22 \mathrm{OK} 778-53$ \\
\hline & Cutting tool/blade & flat metal: ground edges & iron & 22OK778-18 \\
\hline & Cutting tool/blade & flat metal: ground and sharpened edges & iron & $22 \mathrm{OK} 778-24$ \\
\hline & Cutting tool/blade & possible blade fragment & iron & $22 \mathrm{OK} 778-43$ \\
\hline & Cutting tool/blade & flat metal: bifacially sharpened & iron & $22 \mathrm{OK} 778-44$ \\
\hline & Cutting tool/blade & flat metal: bifacially sharpened & iron & $22 \mathrm{OK} 778-45$ \\
\hline & Awl (?) & sheet iron hammered to a point & iron & $22 \mathrm{OK} 778-108$ \\
\hline & Awl (?) & rod stock hammered to point on each end & iron & $22 \mathrm{OK} 850-6$ \\
\hline \multirow[t]{2}{*}{ Skeuomorph } & Celt & ground rod or bar stock & iron & $22 \mathrm{OK} 850-8$ \\
\hline & Celt & ground rod or bar stock & iron & $22 \mathrm{OK} 778-5$ \\
\hline \multirow[t]{4}{*}{ Iberian Hybrids } & Celt & barrel band & iron & $22 \mathrm{OK} 777-6$ \\
\hline & Celt & barrel band (but possible horseshoe fragment) & iron & $22 \mathrm{OK} 778-27$ \\
\hline & Celt & barrel band (or axe or horseshoe fragment) & iron & $22 \mathrm{OK} 778-41$ \\
\hline & Celt & barrel band (or horseshoe fragment) & iron & $22 \mathrm{OK} 778-77$ \\
\hline
\end{tabular}


Table 1. Continued.

\begin{tabular}{|c|c|c|c|c|}
\hline Category & Identification & Comments & $\begin{array}{l}\text { Raw } \\
\text { Material }\end{array}$ & Provenience \\
\hline & Celt & barrel band (or sword or horseshoe fragment) & iron & $22 \mathrm{OK} 778 \mathrm{TU} 2$ \\
\hline & Cutting tool (?) & barrel band stock; grinding on one edge & iron & \\
\hline & Cutting tool (?) & barrel band stock; two sharpened edges & iron & $22 \mathrm{OK} 778-22$ \\
\hline & Uncertain & $\begin{array}{l}\text { barrel band stock: one end cut or bend break; the } \\
\text { other end chopped }\end{array}$ & iron & 22OK778-69 \\
\hline \multirow[t]{18}{*}{ Ornaments } & Pendant & rectangular with hole & copper alloy & $22 \mathrm{OK} 778-10$ \\
\hline & Pendant & rectangular with hole & copper alloy & 22OK778-14 \\
\hline & Pendant & triangular with hole & copper alloy & 22OK778-17 \\
\hline & Pendant & trapezoid with hole & copper alloy & $22 \mathrm{OK} 778-31$ \\
\hline & Pendant & folded with hole & copper alloy & $22 \mathrm{OK} 778-33$ \\
\hline & Pendant & trapezoid with hole & copper alloy & $22 \mathrm{OK} 778-50$ \\
\hline & Pendant & trapezoid with hole & copper alloy & $22 \mathrm{OK} 778-60$ \\
\hline & Pendant & oval with hole & copper alloy & 22OK778-64 \\
\hline & Pendant & trapezoid with folded corners & copper alloy & $22 \mathrm{OK} 778-96$ \\
\hline & Pendant & trapezoid with hole & copper alloy & $22 \mathrm{OK} 932-1$ \\
\hline & Pendant (?) & irregular with small hole & iron & 22OK $778-76$ \\
\hline & Pendant (?) & trapezoid shape & iron & $22 \mathrm{OK} 778-113$ \\
\hline & Tinkler cone & & copper alloy & $22 \mathrm{OK} 778-52$ \\
\hline & Tinkler cone & & copper alloy & $22 \mathrm{OK} 778-56$ \\
\hline & Tinkler cone & & copper alloy & $22 \mathrm{OK} 778-58$ \\
\hline & Tinkler cone & & copper alloy & $22 \mathrm{OK} 778-65$ \\
\hline & Tinkler cone & & copper alloy & $22 \mathrm{OK} 1172-6$ \\
\hline & Uncertain & crushed hollow hemisphere with hole; possible bell & copper alloy & 22OK778-92 \\
\hline \multirow[t]{14}{*}{ Other } & Sheet metal & cut and broken edges & copper alloy & $220 K 778-6$ \\
\hline & Sheet metal & folded and flattened edge & copper alloy & $22 \mathrm{OK} 778-36$ \\
\hline & Sheet metal & smoothed edges & copper alloy & 22OK778-70 \\
\hline & Sheet metal & cut and broken & lead & $22 \mathrm{OK} 778-7$ \\
\hline & Sheet metal & cut and broken & lead & 22OK778-11 \\
\hline & Sheet metal & cut & lead & $22 \mathrm{OK} 778-49$ \\
\hline & Sheet metal & rectangular sheet metal, cut and ground & copper alloy & $22 \mathrm{OK} 778-29$ \\
\hline & Sheet metal & lozenge-shaped sheet metal, cut and ground & copper alloy & $22 \mathrm{OK} 778-32$ \\
\hline & Sheet metal & strip & copper alloy & $22 \mathrm{OK} 778-115$ \\
\hline & $\begin{array}{c}\text { Rectangular } \\
\text { fragment }\end{array}$ & flattened and apparently chewed & lead & $22 \mathrm{OK} 778-87$ \\
\hline & Wrought iron & tip of object with battering & iron & $22 \mathrm{OK} 778-95$ \\
\hline & Wrought iron & flat stock with bend breaks & iron & 22OK778-97 \\
\hline & Wrought iron & flattened rod stock, cut on both ends & iron & $22 \mathrm{OK} 1170-2$ \\
\hline & Wrought iron & band fragment; one end has portion of forged cutout & iron & 22OK1172-1 \\
\hline
\end{tabular}

emphasized that archaeologists recognize only a few metal artifact types with a narrow, sixteenthcentury association in the Southeast (crossbow bolt tips being one example). However, members of our research team's (Legg and DePratter) long-term involvement with archaeological investigations at the major sixteenth-century Spanish settlement of Santa Elena in South Carolina, combined with comparative reviews of other sites in this time horizon in the Southeast (e.g., Blanton 2013; Little 2008; Rodning et al.
2016), suggest to us that certain metal artifacts are likely sixteenth-century diagnostics, particularly when they co-occur with other likely sixteenth-century types. At Stark Farms, these items include expedient celts probably made from barrel bands, rolled copper-alloy beads, and Biscayan-style axes-the last having been common to the sixteenth century, if not limited to it. The horseshoe fragments recovered at Stark Farms are typical of late Medieval forms. Finally, the Stark Farms assemblage is distinctive 
from late seventeenth-century and later assemblages in the Southeast-when objects of European origin were far more common-by the complete lack of domestic types of artifacts, such as scissors, kettles, thimbles, and buckles.

That said, we do not believe that Stark Farms is Chikasha itself. Because the descriptions of local river crossings and the general terrain in the region seem to correspond with the Soto accounts, archaeologists and historians have agreed for some time that Chikasha was likely in the larger area where Stark Farms is located (Atkinson 1987:63-68; Ethridge 2010:11; Johnson and Sparks 1986; Marshall 1986:84-87). Nevertheless, our investigations have not revealed any signs of the widespread burning reported for the town. Nor have our substantial faunal collections provided any of the horse or pig elements one might anticipate with the loss of so many of these animals. Furthermore, our investigations have yet to yield any European ceramics, which might be anticipated with a Spanish encampment. Instead, we believe Stark Farms represents part of the dispersed settlement of the Chikasha province at some distance from the Spanish encampment, which took advantage of Soto's catastrophe to gather exotic goods following the hasty departure of his retinue. Consequently, we hypothesize that the metal objects derived from a combination of small-scale trade with the overwintering Spaniards along with mining of the battle site for objects of value. In light of the Smith and Hally (2020) taxonomy, the context and content of the assemblage seem to reflect a mixture of objects taken in battle and through barter and scavenging.

\section{The Stark Farms Metal Artifact Assemblage}

To date, we have recovered 83 objects of iron, copper or copper alloy, and lead that we believe are likely candidates for a sixteenth-century origin (Table 1). Although the majority have been recovered at 220K778, they are distributed across several of the Stark Farms sites (see Figure 2). There are several attributes of this assemblage that make it stand out from contemporary sites in the Southeast that have yielded similar items. First is the sheer abundance. Except for communities or outposts actually established by Europeans in the 1500s, the quantity of metal artifacts is unusually high compared to contemporary sites in the Southeast. Second, this abundance seems to be limited to the Stark Farms complex. We have conducted metal detecting at numerous recorded sites and open lots in the region without success in finding additional metal artifacts (Smith and Legg 2020; Figure 3). Third, most metal artifacts have been discovered from plow zone contexts by metal detecting, although we have recovered two iron objects in excavations: one iron celt associated with a posthole feature and an unusual tiny, perforated iron sphere-perhaps a bead-from a daub pit. Of course, we wish we had tight contexts for all of these objects. At the very least, however, given that no graves have been encountered in our work at Stark Farms, we believe that the metal artifacts derived mainly from domestic or mundane contexts spread throughout the dispersed settlement; they were not restricted to higher-status individuals as was so often the case elsewhere. Fourth, it is widely believed that most European metal artifacts occurring at Indigenous sixteenth-century sites in the Americas were deposited as relatively intact goods that were only rarely subjected to any significant modification (Berman and Gnivecki 2019:33; Cipolla 2017:18; Mathers 2019). In contrast, many of the Stark Farms artifacts display evidence for light to heavy reworking in the hands of Native Americans (Legg et al. 2019, 2020, as summarized below).

Overall, the metal artifacts fall into several arbitrary categories of hybridity: Unmodified Assemblage Inclusions, Modified Utilitarian, Skeuomorphs, Ornaments, and Iberian hybridity. One of the challenges of research on hybridity is moving away from traditional classifications that may create the false illusion of ontological difference and subsequent melding. We do not claim to have overcome this difficulty in our system, and we will concede that it is polythetic rather than uniform. But, rather than defining groups simply in terms of traditional attributes of raw material (e.g., iron, lead) or European form/function (e.g., reworked axes, modified horseshoes), our classification relies on dimensions that we propose are useful for highlighting various aspects of function, manufacture, and use that 
are relatively-if not completely-consistent within categories.

\section{Unmodified Assemblage Inclusions}

There is some question as to whether the simple inclusion of a "foreign" object into a traditional assemblage constitutes hybridity (Deagan 2013:262; Liebmann 2015:325). Yet, to limit the boundaries of hybrid practices to the object itself would seem to elide arbitrarily the possibility of networked relations between objects of different origin as a form of "relational entanglement" (Stockhammer 2013:16-17). In the sixteenth-century Southeast, this is most clearly manifested in the interment of European objects with Indigenous burials in the South Appalachian and Florida regions. These objects perhaps were analogous to the indexical items found in sacred bundles, which may serve to endow an associated assemblage with enhanced spiritual power (Zedeño 2009).

Given the variety of unmodified objects that derive from plow-zone contexts at Stark Farms, we posit that many were somehow incorporated into households (Figure 4). These include several lead shot in the caliber range of an arquebus; a cast-iron ball (122.5 g), perhaps a small cannon (verso) shot (such artillery pieces are reported for the Soto expedition [Shelby 1993:264-265, 373; Worth 1993a:257]); a copper-alloy ramrod tip; wrought-iron nails consistent with those recovered at Spanish Santa Elena (1566-1587) in South Carolina (South et al. 1988:33-57); a mouth harp; and a perforated medallion displaying a gold-gilt cross that is probably a bridle-bit boss (Figure 5). The diversity of items in this category and the occurrence of unusual military items not normally found as trade objects (e.g., the cannon shot and ramrod tip) are two of the reasons we believe that the assemblage results in part from mining a battle site that was also a winter encampment.

Finally, there are some artifacts that may reflect the compromises of the Soto expedition. Notably, we recovered what appear to be three harness rings manufactured by very crude forging and flattening. It is likely that this kind of expedient retooling became increasingly common through the course of the entrada's passage across the Southeast.

\section{Modified Utilitarian}

A number of metal artifacts were recycled from their original (European) use into functional implements analogous to Native American tools. In many cases, the artifacts were so modified that it was not possible to ascertain the original source object or stock. We have assigned functional categories to them where possible based on general shape and working-edge characteristics, although it is conceivable that they had multiple practical applications. We place these in a utilitarian category, but we readily recognize that this is not the only meaning that may have been attributed to what surely were viewed as unusual and exotic raw materials and forms.

Generic cutting and scraping tools are the most common type in this category. With the exception of one piece of sharply ground copperalloy sheet metal, all of these items were iron. Two of these were likely knife blades, displaying additional evidence for grinding or resharpening of the edge. The others were largely expedientmainly fragments of iron sheet metal with a ground edge. Some objects showed evidence of what appeared to be preparation for further modification into some kind of cutting tool, but without being completed. For instance, one horseshoe fragment exhibits a broken edge initiated by metal fatigue from repeated bending. This was surely a laborious process and one reflecting a lack of access to metal-cutting tools. But no further modification or use was evident.

Iron celts (or possibly adzes) are another common recycled type (Figure 6). They were often manufactured from axes. The so-called Biscayan axe type has been identified at other sixteenthcentury Southeast sites (Blanton 2013:21-22; Linden 2013:33, 35), although it is found in later contexts as well. Axe blades, minus the hafting eye, generally have a shape that would encourage celt manufacture. In some cases, the hafting-eye portion was formed into a celt by flattening into a rectangular panel. Two axes exhibit evidence that the hafting eyes were removed with bend breaks, whereas the blade itself notably shows no additional alteration or recycling. Some axe sections had grinding of broken edges, battering and flattening of thick blade portions to turn them into serviceable edges, and battering on polls in a matter analogous to hammers 


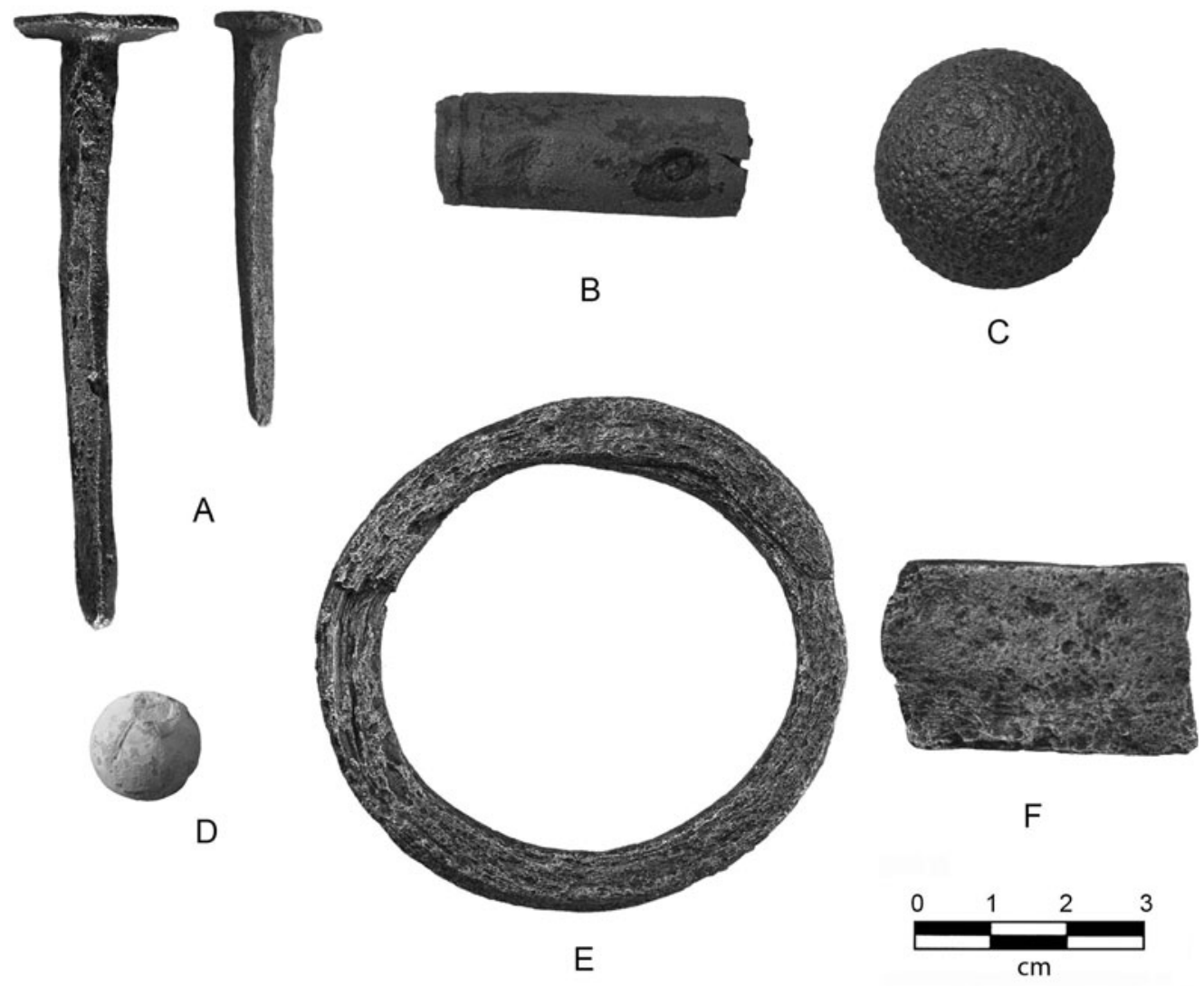

Figure 4. Nonmodified metal artifacts: (A) wrought-iron nails, (B) ramrod tip, (C) cast-iron shot, (D) lead shot, (E) crudely forged harness ring, (F) barrel band section (South Carolina Institute of Archaeology and Anthropology).

(Figure 7). Celts also were manufactured from horseshoe fragments, sections of what appear to be rapier blades, and other thin pieces of modified stock (Figure 6).

Finally, the assemblage contained a number of recycled objects that are unique or do not easily conform to standard taxonomies. As one example, a piece of iron wire stock-likely chain link - had one end battered into an awl-like tip. In another case, portions of the edge of an iron knife blade were deliberately blunted by battering, whereas the rest of the edge was carefully thinned and bifacially sharpened. One horseshoe fragment had grinding on two margins, but it was not an obvious tool.

\section{Skeuomorphs}

There are two examples, both ground iron celts, of skeuomorphs (see Card 2013:8; Howey 2011), which are intentional hybrids created from an imported material to replicate an Indigenous form. The first is virtually a replica of a traditional hardstone celt, smooth and symmetrically ground over the entire surface (Figure 8a). The second is somewhat unusual in that it has a narrowing or waist in plan view (perhaps for hafting), but in side view, it has the classic celt shape (Figure $8 b$ ). These objects would have required a large source piece of iron stock, and by all appearances, their manufacture was labor intensive.

\section{Iberian Hybridity}

Silliman (2015) suggests that there needs to be more emphasis on European contributions to hybrid forms and practices in colonial settings. Heather Trigg (2020) has made this case in her study of seventeenth-century Spanish households in northern New Mexico, where hybrid forms of architecture, pottery, and culinary regimes speak to the intermingling of Indigenous 


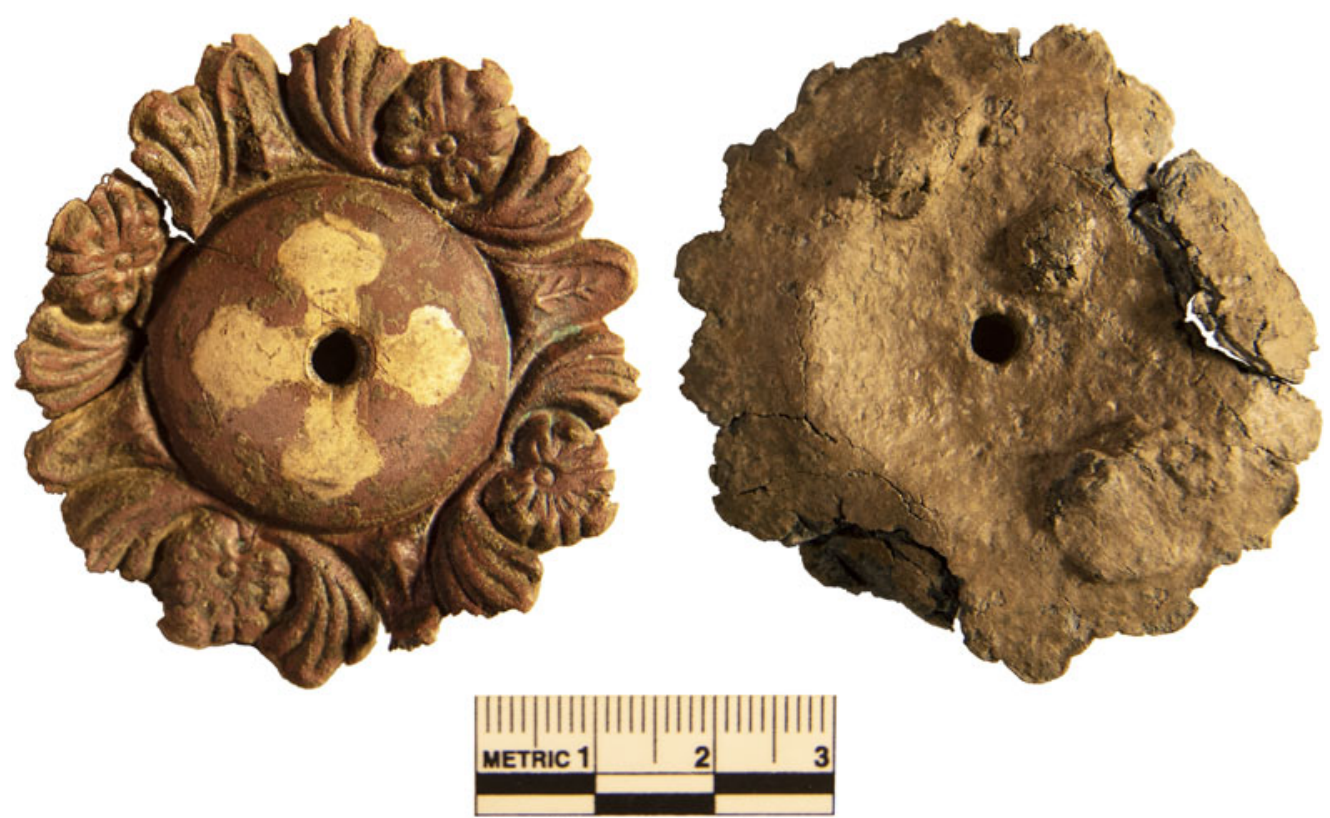

Figure 5. Possible bridle boss (South Carolina Institute of Archaeology and Anthropology).

and European peoples sharing the same spaces on Spanish ranches and farms. The assemblage from Stark Farms emphasizes that even this category of hybridity is characterized by important variation in that Soto expedition members may have been purposefully making metal forms shaped to Indigenous tastes rather than for their own consumption.

Specifically, iron barrel bands were used to manufacture flat, rectangular iron celts or adzes (Figures $6 \mathrm{f}$ and 6h). As implied by the name, these were fragments cut from the iron bands normally used to hold barrel staves in place. Barrel bands of the early colonial era were heavy, wrought-iron pieces rather than sheet metal, representing a particularly flexible source of raw stock for tool manufacture. Typically, barrel band celts have bifacially ground bits. Their occurrence at other sixteenth-century Southeast sites (e.g., Blanton 2013:22-23; DePratter and Smith 1980:74-76) suggests that they may have been made specifically for gifting and trade with Native Americans. In particular, the consistent size of examples from some of these sites is suggestive of mass production by Spanish blacksmiths (Legg et al. 2020:53). It is interesting that the examples from Stark Farms are generally smaller than those reported in contemporary sites to the east. This may indicate that the Soto expedition was attempting to conserve a diminishing store of such supplies.

\section{Ornaments}

Given a deep history of copper use in the Southeast, copper or copper alloy is the one raw material carried by the Soto expedition with which Native Americans would have had some familiarity. What is unusual is that the colonial influx of copper alloy into the Southeast appears to have initiated a new repertoire of forms and uses. Our preliminary pXRF analysis of the Stark Farms copper-base ornaments indicates that most are brass. Many are either trapezoidal pendants or "tinkler cones"-items likely attached to clothing (Figure 9). This supposition is supported by the occurrence of a possible silk fragment under the folded ears of one of the pendants and cordage in two of the cones. Tinkler cones are widespread on later sites throughout eastern North America, but they have been documented in sixteenth-century contexts at the Berry site in western North Carolina (Rodning et al. 2016:330). Rolled copper-alloy beads were also a common ornament type. Data supporting the 


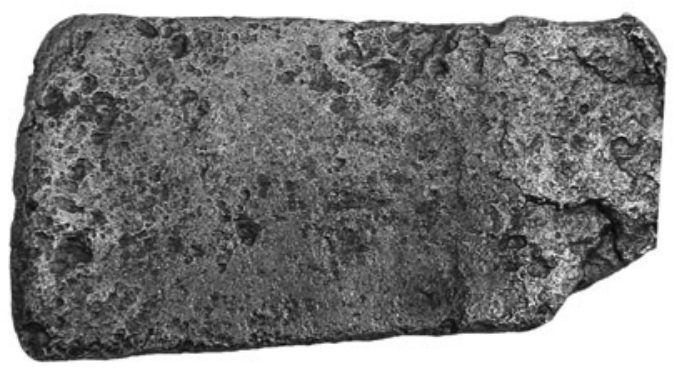

A

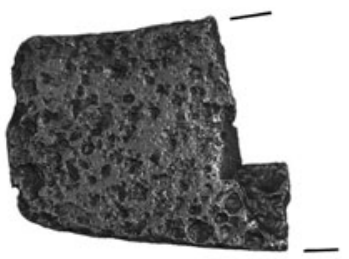

C

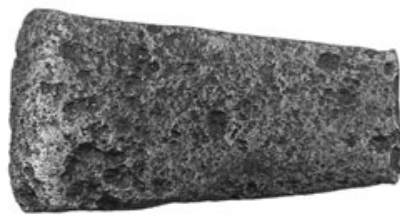

$\mathrm{F}$

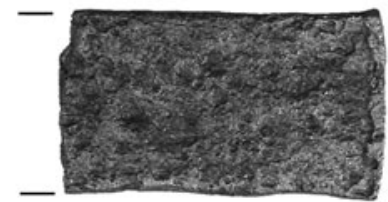

$\mathrm{H}$

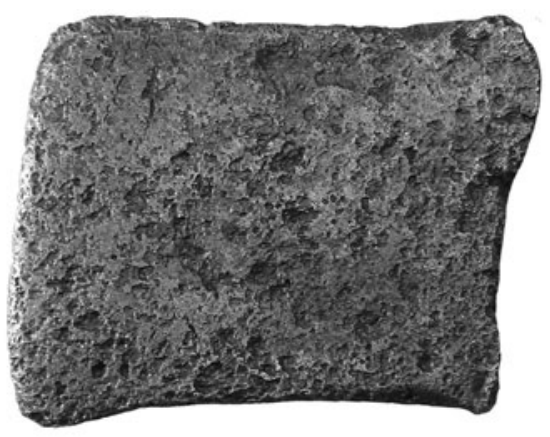

B
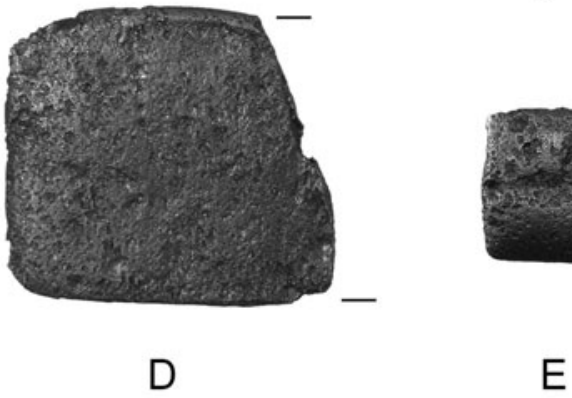

$E$

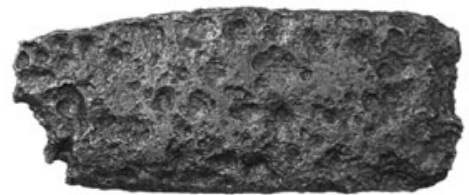

G

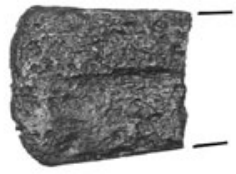

।

Figure 6. Celt forms: (A, B) axe eye sections, (C, D) horseshoe fragments, (E, I) possible rapier blade fragments, (F, H) likely barrel bands, (G) possible axe blade (South Carolina Institute of Archaeology and Anthropology).

Indigenous manufacture of copper-base objects at later-period sites (Bradley 1987; Ehrhardt 2013) suggest that the specimens at Stark Farms likewise were made by local inhabitants. This inference is buttressed by a vernacular manufacturing technology that did not rely on a forge, but that was characterized by (1) bendbreaking and folding rather than cutting to modify pieces, (2) the frequent occurrence of sizable untrimmed irregularities, and (3) laborious grinding and smoothing of the edges.

On Southeastern sites dating to the 1600 s and later, these kinds of copper-alloy artifacts were frequently made from thin brass kettles and pots (Brain 1979:164-185). The Stark Farms assemblage lacks diagnostic elements of metal 

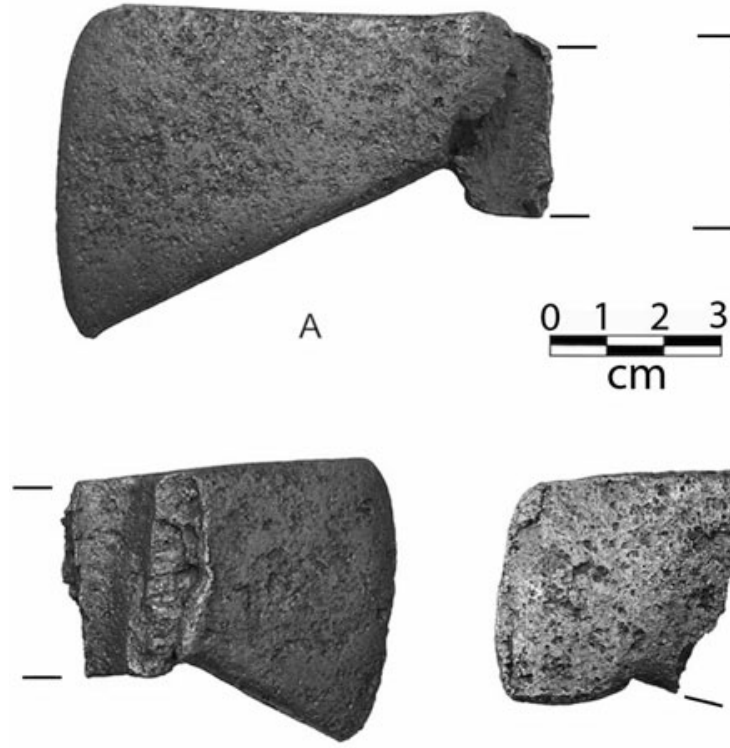

C

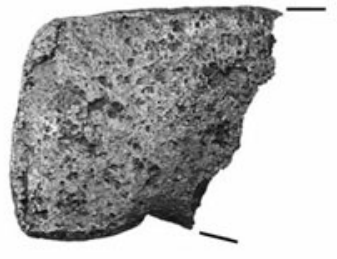

$\mathrm{D}$
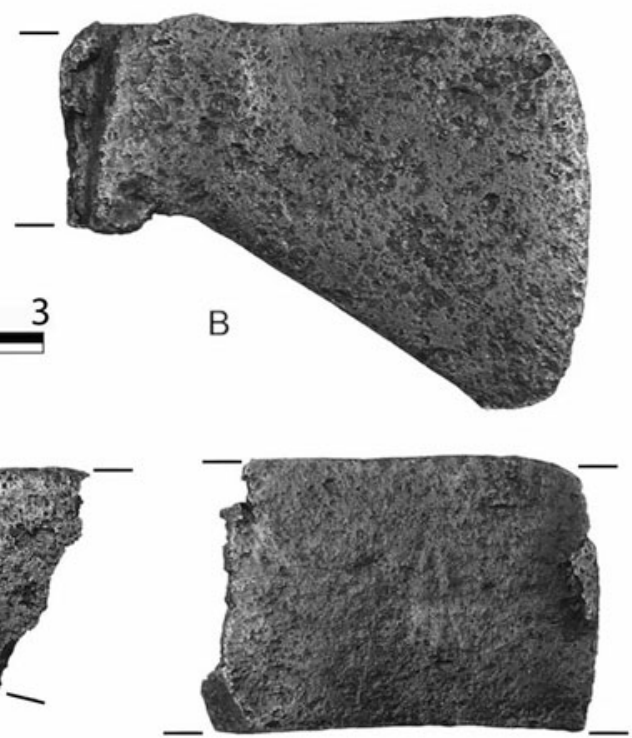

E

Figure 7. Axes in varying states of modification (South Carolina Institute of Archaeology and Anthropology).
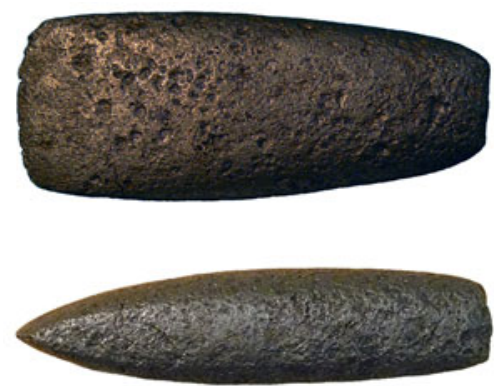

A

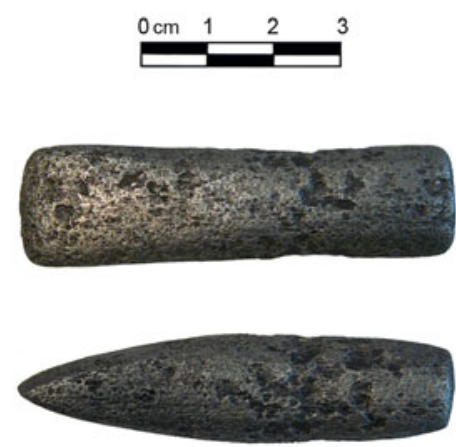

B

Figure 8. Skeuomorph celts (South Carolina Institute of Archaeology and Anthropology). (Color online) vessels, such as bail attachments and rolled rim fragments. Copper pitchers and cauldrons have been recovered from the Luna expedition shipwrecks dating only 20 years later (Bratten 2018). Consequently, even lacking the characteristic elements, it is possible that remnants of similar containers were used to produce the ornaments at Stark Farms.

\section{Unknown/Other}

There are a number of metal artifacts from Stark Farms that do not readily fit into traditional archaeological categories. These are not distinctively sixteenth century, but they often occurred in or near clusters of our more recognizable metal objects on the site. Many are modified, irregular pieces of unknown function. In addition to pieces of worked sheet-metal copper alloy described in our discussion on ornaments, there are also several fragments of cut and broken sheet lead. One rectangular lead fragment was apparently flattened and chewed. Some of the generic objects reflect initial or experimental working before loss or discard. For example, one wrought-iron chain link was opened by flattening the forge-welded join, a tactic likely to be employed if one did not have any metal-working 


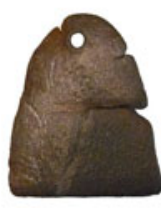

A

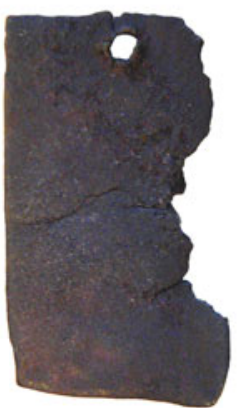

F

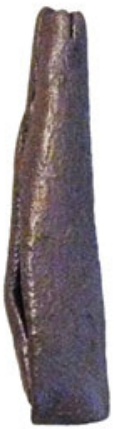

J

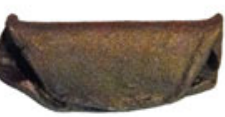

$\mathrm{O}$

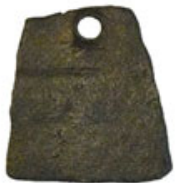

B

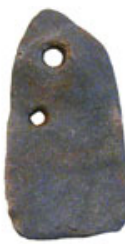

C

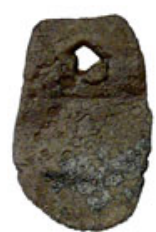

D

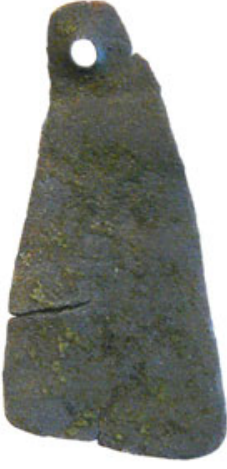

E

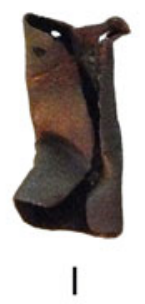

$\mathrm{H}$

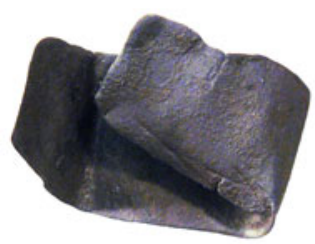

M

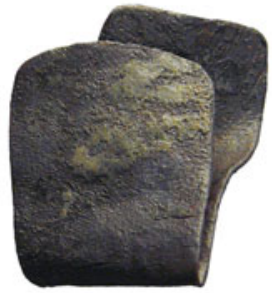

$\mathrm{N}$

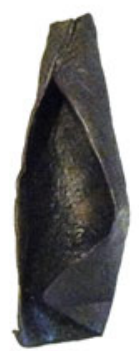

$\mathrm{K}$

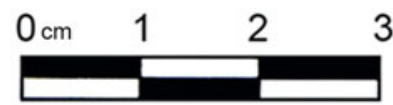

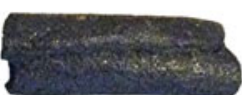

$\mathrm{P}$

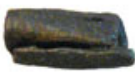

Q

Figure 9. Copper base objects: (A-H) ornaments perforated for suspension, (I) loosely rolled tube, (J-L) tinkler cones, (M-O) folded strips, (P, Q) rolled tube beads (South Carolina Institute of Archaeology and Anthropology). (Color online) 
tools available. Interestingly, the modest chain links in the assemblage are particularly emblematic of the antagonisms between Spaniards and Native Americans. The Soto expedition carried a large amount of iron chain for various purposes, including shackling Native Americans as captives and porters (e.g., Robertson 1993:68). Before his departure from Chikasha, Soto had demanded that the chief surrender a large number of people as porters, likely setting into motion the events that led to the battle (Robertson 1993:107).

\section{A Deeper History of Heterogeneous Hybridity}

Rather than arguing that the assemblage of Stark Farms metal artifacts manifests a stage within a predictable historical sequencing of hybridity (nascent colonialism to mature colonialism, if you will), we believe that our study suggests two things. First, hybridity can be a dialectical meshing of interruption and novelty on the one hand and continuity on the other. We have segregated the Stark Farms metal artifacts into various arbitrary categories of hybridity that emphasize stylistic and technological idiosyncrasies employed in introduced raw materials. Yet, it is also useful to step back and contemplate the gestalt of the corpus of objects, predicated on the notion that the emergent property of an assemblage may strike a different register in the materiality of hybridity than revealed by solely focusing on constituent elements (for various perspectives on addressing copresencing of traits, see Hauser 2017; Sheptak and Joyce 2019; Stahl 2010). From this perspective, the metal artifacts confer a collective sense of improvisation weighted toward "staying the same"-a dimension of hybridity and entanglement in colonial situations that bears more attention (Silliman 2013:492). They highlight Marshall Sahlins's (1993:17) dictum that "the first commercial impulse of the people is not to become just like us, but more like themselves."

In this sense, although many of the hybrid aspects of the Stark Farms metal artifacts may have been new, the practices were time honored. Liebmann (2015:322) asks, "Why do we label some objects hybrid, yet ignore the complex multicultural biographies of others?" We now recognize the entire Mississippian period (ca. AD 1000-1600) as a dynamic time of population movement, social churn, and cultural mixture in which material practices have been characterized as hybrid and coalescent (e.g., Alt 2006; Blitz 1999; Cable 2020). Wall-trench architecture, which seems to have its origins in the Cahokia region of west-central Illinois (Pauketat 2007), appears on some sites in eastern Mississippi early in the Mississippian period, where it commingled with the dominant single-set-post style of houses (Boudreaux et al. 2018; O'Hear et al. 1981). A small percentage of the ceramics at Stark Farms exhibit decorative treatments associated with the Lower Mississippi Valley (Phillips 1970:83, 151) and western Alabama (Knight 2010:20, 39-40), but they rely on local pastes and tempers (Boudreaux et al. 2020: Table 3.4; Smith 2017). Furthermore, this was a time of local migration and endemic ceramic hybridity. In the AD 1300s and 1400s, there was a population flow from the Upper Tombigbee Valley and associated drainages onto the Black Prairie $40 \mathrm{~km}$ to the west, accompanied by a shift from freshwater mussel shell temper to fossil shell temper (Johnson 1996). At sites occupied before this technological transition was largely complete in the 1600 s, it is common to find pottery with mixtures of both at Stark Farms and other sites in the Black Prairie (Sorresso and Quinn 2020). Well before the arrival of the Spaniards, there was an established arc of social, material, and biological fluidity, and it was common to incorporate new peoples and synthesize material traditions from near and far. The Stark Farms metal artifacts are just as much a product of that history as they are of European incursions.

This brings us to our second point. Even if hybrid practices are multithreaded and deeply rooted, the relations of power that they embody can be qualitatively different. It is this dimension that underscores the colonial encounter and its aftermath. Much of the anxiety over concepts such as hybridity and creolization seems to be ontology centric, largely focused on identity and origins. This rightfully draws attention to who may have produced or consumed the object. But hybrid entities as agents or media of contestations over authority and power are as much 
a matter of externalities as they are internalities. In other words, the ways in which colonial period metal artifacts were modified and became elements of assemblages were also wedded to the multiscalar networks that delivered the original objects to various parts of the globe (see Hofman et al. 2014; Knappett 2013). By networks, we do not necessarily mean formal lattices that in some circumstances can be highly useful for modeling the flow of peoples, things, and ideas. Instead, we refer to more nebulous webs of regional and panregional relations constituted within historical settings. The emergent Atlantic World of the 1500 s and 1600s was one such system (Armitrage and Braddick 2009; Benjamin 2009; Orser 2018), eventually developing the institutions that would tether Indigenous peoples to colonial powers and spur the kinds of routinized circulation of objects and entrenched hybrid practices that have drawn so much attention from postcolonial scholarship.

From what we know of the history of the interior Southeast following the immediate arrival of Europeans, these globalized networks had yet to sediment fully, and institutions of colonial management and control were still taking shape. The attenuated nature of colonial encroachments is emphasized by the frequent occurrence of European metal objects in mortuary assemblages of the era, the outcome of a tradition of gifting whereby European parties consistently needed to seek the favor of local polities to acquire food and other resources as well as to ensure safe passage (Smith and Hally 2020). Inventories for the Juan Pardo expeditions (1566-1568) into the interior Southeast on behalf of the Spanish crown specifically refer to objects earmarked as gifts (DePratter and Smith 1980). The occurrence of metal artifacts at sixteenth-century sites that likely did not have direct contact with European expeditions suggests that Indigenous elites often disbursed their gifts to satellite communities in a system of patronage and debt obligations (Smith and Hally 2020). These endemic regional networks of factions and asymmetry that privileged some individuals and groups above others were only loosely coupled to the emerging Atlantic World.

Stark Farms appears to be an example of when these kinds of directed transactions collapsed in a violent outcome, where significant amounts of European material were released in a manner that seems to have been structured only by very localized networks. This brief spell of abundance appears to have fostered a highly improvisational climate of working and reworking novel materials and forms. The kind of event-like scenario as an impulse to hybrid practices may not have been so rare. Months before their arrival at Chikasha, Soto's forces had suffered an even larger loss of matériel in a pitched battle at the town of Mabila, located in western Alabama (Knight 2009; Robertson 1993:105). On the same time horizon in the American Southwest, the Francisco Vázquez de Coronado expedition engaged in a major conflict with Indigenous communities in the Middle Rio Grande drainage, leaving an abundance of military artifacts at Pueblo sites in the Tiguex War of 1540-1542 (Mathers 2020; Schmader 2016). Furthermore, the scattered remains of failed colonial settlements and entradas in the 1500 s throughout the Southeast provided yet another potentially rich source of providential European material. In short, the sixteenth century in southeastern North America was a period when considerable latitude in the exercise of hybrid practices relatively unencumbered from consistent European influence or intervention was possible.

\section{Conclusion}

\section{Meghan Howey observes that}

thresholds of colonial encounter are critical liminal times where "Other," "Self," and "West" are not fully defined but emergent, yet details on the happenings of these thresholds are often swamped by data on the events before and after which are more abundant archaeologically and historically [2011:333].

There are such instances, however-Stark Farms being one-where the data on hybrid practices are not so impacted by the swamping effect. With the departure of Soto from northern Mississippi in 1541, there is no evidence for any kind of significant European presence-or notable accumulations of metal artifacts-in this region for another 150 years. As a result, the hybrid characteristics of the metal assemblage at Stark Farms 
have a wide-ranging and experimental sensibility, seemingly shaped by Indigenous conventions rather than by, or against, European norms. Ironically, the various categories that have been proposed to distinguish cultural mixing - organic hybridity and intentional hybridity (Bakhtin 1981), relational entanglement and material entanglement (Stockhammer 2013), and the like-themselves become blurred as hybrid taxonomic conventions in many ways, as manifested in the Stark Farms assemblage.

Given the complexities of cultural mixing enveloped in just one case study, it is understandable why there is so much caution among archaeologists in committing to hybridity, creolization, entanglement, or some other alternative. Still, even in a remote setting where Native American interests held sway, the initial, unsettling temblors of colonial incursions were likely having an impact on communities and their material cultures. In many localities in the sixteenth-century Southeast, hybrid mortuary assemblages speak to the first attempts by Europeans to finesse local networks of power through selective patronage. Their gifts entered into established Indigenous traditions of factions and status that seem to have always been precarious. In addition, they were the first instances of Europeans attempting to cultivate the standing of individuals who could help their cause-a practice that later would add to the destabilization of Indigenous polities throughout the Southeast. As a variation on these themes, Stark Farms seems to represent an instance of the failure of colonial tactics and the unintentional release of an abundance of European material accompanied by a fleeting moment of widespread access to otherwise rare and unusual objects.

As is evident from this study, major challenges remain in reaching any kind of consensus on how to conceptualize research on cultural mixing in colonial settings. A singular difficulty is that debates over hybridity and related terms have been theoretically sophisticated, but it seems that far more detailed case studies-rather than cursory vignettes or brief illustrations that serve to prop up a given theoretical angle-will be required to achieve greater resolution over the expression and framing of hybridity, entanglement, and the like. In this respect, we subscribe to Diana Loren's admonition: "The more productive theories of hybridity are those that problematize the term and seek to investigate the nuances and details in the entanglement of people and objects in specific historical contexts" (2013:152-153).

Acknowledgments. We are deeply grateful to the Chickasaw Nation and their Chickasaw Explorers Program for initiating and funding much of this research. Portions of our fieldwork were also made possible by a grant (\#9831-16) from the National Geographic Society. Mark Hauser and Diana Loren provided insightful commentaries on an earlier draft of this work. Three anonymous reviewers as well as Lynn Gamble provided highly useful constructive criticisms and suggestions as part of the formal review process. We greatly appreciate their insights. Finally, we extend our gratitude to the many gracious landowners who made this work possible.

Data Availability Statement. The materials discussed in this article are currently curated at the South Carolina Institute of Archaeology and Anthropology, Columbia, South Carolina.

\section{Notes}

1. Indigenous metal objects (mainly copper) that predate the arrival of Europeans are also found in the American Southeast. Here, the term "metal artifacts" is reserved for objects hypothesized to derive from an encounter with the Soto expedition.

2. Also known as Chicasa. Here, we use the Chickasaw rendering of the name.

3. As sponsors of much of our research, the Chickasaw Nation reviews our publications for consistency with its histories. Furthermore, the Chickasaw Nation actively provides information on the Chickasaw Explorers program and its collaboration with universities (https://www.chickasaw.net/ Services/Culture/Chickasaw-Explorers-Program.aspx), in addition to its perspectives on important aspects of its history through popular media portals (e.g., for the Soto expedition: https://www.chickasaw.tv/profiles/hernando-de-soto-profile).

4. As with most metal-detecting projects, ours recovered scores of modern objects in addition to those of uncertain provenience and age. Our sorting system involved a four-part triage: (1) modern, (2) premodern but likely postdating the 1600 s (e.g., lead shot of a caliber common to the 1700 s and 1800s), (3) potential sixteenth century (e.g., lead shot of a caliber common to arquebuses, copper-alloy ornaments such as tinkler cones), and (4) likely sixteenth century (e.g., diagnostic celt forms and Medieval horse shoes). Our analysis focuses on the last two categories.

\section{References Cited}

Acabado, Stephen

2017 The Archaeology of Pericolonialism: Responses of the "Unconquered" to Spanish Conquest and Colonialism in Ifugao, Philippines. International Journal of Historical Archaeology 21:1-26. 
Alt, Susan M.

2006 The Power of Diversity: The Roles of Migration and Hybridity in Culture Change. In Leadership and Polity in Mississippian Society, edited by Brian M. Butler and Paul D. Welch, pp. 289-308. Center for Archaeological Investigations Occasional Paper No. 33. Southern Illinois University, Carbondale.

Armitrage, David, and Michael J. Braddick (editors)

2009 The British Atlantic World, 1500-1800. 2nd ed. Palgrave Macmillan, New York.

Atkinson, James R.

1979 A Historic Indian Settlement in Oktibbeha County, Mississippi. Journal of Alabama Archaeology 25:61-82.

1987 The De Soto Expedition through North Mississippi in 1540-1541. Mississippi Archaeology 22(1):61-74.

Bakhtin, Mikhail

1981 The Dialogic Imagination. Translated by Caryl Emerson and Michael Hosquist. University of Texas Press, Austin.

Bayman, James M.

2009 Technological Change and the Archaeology of Emergent Colonialism in the Kingdom of Hawai'i. International Journal of Historical Archaeology 13:127-157.

Benjamin, Thomas

2009 The Atlantic World: Europeans, Africans, Indians and Their Shared History, 1400-1900. Cambridge University Press, Cambridge.

Berman, Mary Jane, and Perry L. Gnivecki

2019 Colonial Encounters in Lucayan Contexts. In Material Encounters and Indigenous Transformations in the Early Colonial Americas: Archaeological Case Studies, edited by Corinne L. Hofman and Floris W. M. Keehnen, pp. 32-57. Brill, Leiden, Netherlands.

Bhabha, Homi

1994 The Location of Culture. Routledge, London.

Blanton, Dennis B.

2013 Point of Contact: Archaeological Evaluation of a Potential De Soto Encampment in Georgia. Fernbank Museum of Natural History, Atlanta, Georgia.

2020 Conquistador's Wake: Tracking the Legacy of Hernando de Soto in the Indigenous Southeast. University of Georgia Press, Athens.

Blitz, John H.

1993 Ancient Chiefdoms of the Tombigbee. University of Alabama Press, Tuscaloosa.

1999 Mississippian Chiefdoms and the Fission-Fusion Process. American Antiquity 64:577-592.

Boudreaux, Edmond A., III, Charles R. Cobb, Emily Clark, Chester B. DePratter, James B. Legg, Brad R. Lieb, Allison M. Smith, and Steven D. Smith

2020 The Early Contact Period in the Black Prairie of Northeast Mississippi. In Contact, Colonialism, and Native Communities in the Southeastern United States, edited by Edmond A. Boudreaux III, Maureen Meyers, and Jay K. Johnson, pp. 35-56. University of Florida Press, Gainesville.

Boudreaux, Edmond A., III, Brad R. Lieb, Allison M. Smith, Stephen G. Harris, and Charles R. Cobb

2018 Investigations at the Butler Mound Site in Northeast Mississippi. Submitted to Chickasaw Nation Department of Culture and Humanities. Copies available from University of Mississippi Center for Archaeological Research, University, Mississippi.

Bradley, James W.

1987 Evolution of the Onondaga Iroquois: Accommodating Change, 1500-1655. Syracuse University Press, Syracuse, New York.
Brain, Jeffrey P.

1979 Tunica Treasure. Papers of the Peabody Museum of Archaeology and Ethnology, Vol. 71. Harvard University, Cambridge, Massachusetts.

Bratten, John R.

2018 What They Left Behind: The Artifact Assemblage. In Florida's Lost Galleon: The Emanuel Point Shipwreck, edited by Roger C. Smith, pp. 122-206. University Press of Florida, Gainesville.

Cable, John S.

2020 Megadrought in the Carolinas: The Archaeology of Mississippian Collapse, Abandonment and Coalescence. University of Alabama Press, Tuscaloosa.

Card, Jeb J.

2013 Introduction. In The Archaeology of Hybrid Material Culture, edited by Jeb J. Card, pp. 1-21. Center for Archaeological Investigations Occasional Paper No. 39. Southern Illinois University Press, Carbondale.

Carpenter, Cari M.

2008 Seeing Red: Anger, Sentimentality, and American Indians. Ohio State University Press, Columbus.

Cipolla, Craig N.

2017 Indigenous People and Foreign Objects: Rethinking Consumption in American Archaeology. In Foreign Objects: Rethinking Indigenous Consumption in American Archaeology, edited by Craig N. Cipolla, pp. 3-28. University of Arizona Press, Tucson.

Clark, Emily C.

2017 The Analysis of Contact-Era Settlements in Clay, Lowndes, and Oktibbeha Counties in Northeast Mississippi. Master's thesis, Department of Sociology and Anthropology, University of Mississippi, Oxford.

Clayton, Lawrence A., Vernon James Knight Jr., and Edward C. Moore (editors)

1993 The De Soto Chronicles: The Expedition of Hernando de Soto to North America in 1539-1543. 2 vols. University of Alabama Press, Tuscaloosa.

Cobb, Charles R.

2003 Introduction: Framing Stone Tool Traditions after Contact. In Stone Tool Traditions in the Contact Era, edited by Charles R. Cobb, pp. 1-12. University of Alabama Press, Tuscaloosa.

Deagan, Kathleen

2013 Hybridity, Identity, and Archaeological Practice. In The Archaeology of Hybrid Material Culture, edited by Jeb J. Card, pp. 260-276. Center for Archaeological Investigations, Occasional Paper No. 39. Southern Illinois University, Carbondale.

DePratter, Chester B., and Marvin T. Smith

1980 Sixteenth Century European Trade in the Southeastern United States: Evidence from the Juan Pardo Expeditions (1566-1568). In Spanish Colonial Frontier Research, edited by Henry F. Dobyns, pp. 67-77. Center for Anthropological Studies, Albuquerque, New Mexico.

DuVal, Kathleen

2006 The Native Ground: Indians and Colonists in the Heart of the Continent. University of Pennsylvania Press, Philadelphia.

Ehrhardt, Kathleen L.

2013 "Style" in Crafting Hybrid Material Culture on the Fringes of Empire: An Example from the Native North American Midcontinent. In The Archaeology of Hybrid Material Culture, edited by Jeb J. Card, pp. 364-396. Center for Archaeological Investigations Occasional Paper No. 39. Southern Illinois University Press, Carbondale. 
Ethridge, Robbie

2010 From Chicaza to Chickasaw: The European Invasion and the Transformation of the Mississippian World, 1540-1715. University of North Carolina Press, Chapel Hill.

Ewen, Charles, and John H. Hann

1998 Hernando de Soto among the Apalachee: The Archaeology of the First Winter Encampment. University Press of Florida, Gainesville.

Gosden, Chris

2004 Archaeology and Colonialism: Cultural Contact from 5000 BC to the Present. Cambridge University Press, Cambridge.

Hally, David J.

2008 King: The Social Archaeology of a Late Mississippian Town in Northwestern Georgia. University of Alabama Press, Tuscaloosa.

Hauser, Mark William

2017 A Political Ecology of Water and Enslavement: Water Ways in Eighteenth-Century Caribbean Plantations. Current Anthropology 58:227-256.

Hauser, Mark W., Douglas V. Armstrong, Diane Wallman, Kenneth G. Kelly, and Lennox Honychurch

2019 Where Strangers Met: Evidence for Early Commerce at LaSoye Point, Dominica. Antiquity 93:1-8.

Hofman, Corinne, Angus Mol, Menno Hoogland, and Roberto Valcárcel Rojas

2014 Stages of Encounters: Migration, Mobility and Interaction in the Pre-Colonial and Early Colonial Caribbean. World Archaeology 46:590-609.

Hogue, S. Homes, and Evan Peacock

1995 Environmental and Osteological Analysis at the South Farm Site (22OK535), A Mississippian Farmstead in Oktibbeha County, Mississippi. Southeastern Archaeology 14:31-45.

Howey, Meghan C. L.

2011 Colonial Encounters, European Kettles, and the Magic of Mimesis in the Late Sixteenth and Early Seventeenth Century Indigenous Northeast and Great Lakes. International Journal of Historical Archaeology 15:329-357.

Hudson, Charles, and Carmen Chaves Tesser

1994 Introduction. In The Forgotten Centuries: Indians and Europeans in the American South, 1521-1704, edited by Charles Hudson and Carmen Chaves Tesser, pp. 1-14. University of Georgia Press, Athens.

Johnson, Jay K.

1996 The Nature and Timing of the Late Prehistoric Settlement of the Black Prairie in Northeast Mississippi: A Reply to Hogue, Peacock, and Rafferty. Southeastern Archaeology 15:244-249.

Johnson, Jay K., and John T. Sparks

1986 Protohistoric Settlement Patterns in Northeast Mississippi. In The Protohistoric Period in the Mid-South: 1500-1700, edited by David H. Dye and Ronald C. Brister, pp. 64-81. Archaeological Report No. 18. Mississippi Department of Archives and History, Jackson, Mississippi.

Jordan, Kurt A.

2014 Pruning Colonialism: Vantage Point, Local Political Economy, and Cultural Entanglement in the Archaeology of Post-1415 Indigenous Peoples. In Rethinking Colonial Pasts through Archaeology, edited by Neal Ferris, Rodney Harrison, and Michael Wilcox, pp. 103-120. Oxford University Press, Oxford
Jordan, Kurt A., and Peregrine A. Gerard-Little

2019 Neither Contact nor Colonial: Seneca Iroquois Local Political Economies, 1650-1754. In Indigenous Persistence in the Colonized Americas: Material and Documentary Perspectives on Entanglement, edited by Heather Law Pezzarossi and Russell N. Sheptak, pp. 39-56. University of New Mexico Press, Albuquerque. Knappett, Carl (editor)

2013 Network Analysis in Archaeology: New Approaches. Oxford University Press, Oxford.

Knight, Vernon James, Jr. (editor)

2009 The Search for Mabila: The Decisive Battle between Hernando de Soto and Chief Tuscalusa. University of Alabama Press, Tuscaloosa.

Knight, Vernon James, Jr.

2010 Mound Excavations at Moundville: Architecture, Elites, and Social Order. University of Alabama Press, Tuscaloosa.

Latour, Bruno

1991 We Have Never Been Modern. Translated by Catherine Porter. Harvard University Press, Cambridge, Massachusetts.

Legg, James B., Dennis B. Blanton, Charles R. Cobb, Steven D. Smith, Brad R. Lieb, and Edmund A. Boudreaux III

2019 An Appraisal of the Indigenous Acquisition of Contact Era European Metal Objects in Southeastern North America. International Journal of Historical Archaeology 23:81-102.

Legg, James B., Charles R. Cobb, Edmund A. Boudreaux III, Brad R. Lieb, Chester B. DePratter, and Steven D. Smith

2020 The Stark Farm Enigma: Evidence of the Chicasa (Chikasha)-Soto Encounter in Mississippi? In Modeling Entradas: Sixteenth-Century Assemblages in North America, edited by Clay Mathers, pp. 43-67. University of Florida Press, Gainesville.

Liebmann, Matthew

2013 Parsing Hybridity: Archaeologies of Amalgamation in Seventeenth-Century New Mexico. In The Archaeology of Hybrid Material Culture, edited by Jeb J. Card, pp. 25-49. Center for Archaeological Investigations Occasional Paper No. 39. Southern Illinois University Press, Carbondale.

2015 The Micky Mouse Kachina and Other "Double Objects": Hybridity in the Material Culture of Colonial Encounters. Journal of Social Archaeology 15:319_ 341 .

Linden, Sarah Elizabeth

2013 Metals of Conquest: A Study Using Portable X-Ray Fluorescence Spectrometry in the Metallurgical Analysis of Two Sixteenth-Century Spanish Expeditions. Master's thesis, Department of Anthropology, University of West Florida, Pensacola.

Little, Keith J.

2008 European Artifact Chronology and Impacts of Spanish Contact in the Sixteenth-Century Coosa Valley. PhD dissertation, Department of Anthropology, University of Alabama, Tuscaloosa.

Loren, Diana D.

2013 Considering Mimicry and Hybridity in Early Colonial New England: Health, Sin and the Body "Behung with Beades." Archaeological Review from Cambridge 28(1):151-168.

Marshall, Richard A.

1986 The Protohistoric Component at the Lyon's Bluff Site Complex, Oktibbeha County, Mississippi. In The Protohistoric Period in the Mid-South, 1500-1700: 
Proceedings of the 1983 Mid-South Archaeological Conference, edited by David Dye and Ronald Brister, pp. 82-88. Archaeological Report No. 18. Mississippi Department of Archives and History, Jackson.

Mathers, Clay

2019 War and Peace in the Sixteenth-Century Southwest: Object-Oriented Approaches to Native-European Encounters and Trajectories. In Material Encounters and Indigenous Transformations in the Early Colonial Americas: Archaeological Case Studies, edited by Corinne L. Hofman and Floris W. M. Keehnen, pp. 308332. Brill, Leiden, Netherlands.

2020 The Grammar and Syntax of Battle: Kuaua Pueblo, the Pueblo de la Cruz, and Constructing Analytical Frameworks for the Tiguex War (1540-1542). In A Lifelong Journey: Papers in Honor of Michael P. Marshall, edited by Emily J. Brown, Matthew J. Barbour, and Genevieve N. Head, pp. 175-187. Papers Vol. 46. Archaeological Society of New Mexico, Albuquerque.

McEwan, Bonnie (editor)

1993 The Spanish Missions of La Florida. University Press of Florida, Gainesville.

Milanich, Jerald T.

1999 Laboring in the Fields of the Lord: Spanish Missions and Southeastern Indians. Smithsonian Institution, Washington, DC.

Mitchem, Jeffrey M.

1989 The Ruth Smith, Weeki Wachee, and Tatham Mounds: Archaeological Evidence of Early Spanish Contact. Florida Anthropologist 42:317-339.

Mullins, Paul R., and Robert Paynter

2000 Representing Colonizers: An Archaeology of Creolization, Ethnogenesis, and Indigenous Material Culture among the Haida. Historical Archaeology 34(3):73-84.

O’Hear, John W., Clark Larsen, Marge M. Scarry, John C. Phillips, and Erica Simons

1981 Archaeological Salvage Excavations at the Tibbee Creek Site (22Lo600), Lowndes County, Mississippi. Submitted to U.S. Army Corps of Engineers Mobile District. Copies available from Mississippi State University, Department of Anthropology, Starkville.

Orser, Charles E., Jr.

2018 An Archaeology of the English Atlantic World, 1600-1700. Cambridge University Press, Cambridge.

Palmié, Stephan

2013 Mixed Blessings and Sorrowful Mysteries. Current Anthropology 54:463-482.

Pauketat, Timothy R.

2007 Chiefdoms and Other Archaeological Delusions. AltaMira Press, Walnut Creek, California.

Peacock, Evan

1995 Test Excavations at an Upland Mississippian Site in Oktibbeha County, Mississippi. Mississippi Archaeology 30(2):1-20.

Phillips, Philip

1970 Archaeological Survey in the Lower Yazoo Basin, Mississippi, 1949-1955. Papers Vol. 60. Peabody Museum of Archaeology and Ethnology, Cambridge, Massachusetts.

RabbySmith, Steve, Michael Creswell, and James C. Pritchard 2015 Archaeological Survey of the Starkville Development Site, Oktibbeha County, Mississippi. Submitted to Headwaters Natural Resources Consulting. Copies available from Brockington and Associates, Atlanta, Georgia.

Rafferty, Janet

2001 Determining Duration at Prehistoric Sites: Short-
Term Sedentary Settlement at Josey Farm, NE Mississippi. Journal of Field Archaeology 28:347-366.

Rafferty, Janet E., and S. Homes Hogue

1999 Test Excavations at Six Sites in Oktibbeha County, Mississippi. Cobb Institute of Archaeology, Mississippi State University, Starkville. Report submitted to the Mississippi Department of Transportation, Jacksonville. Rifkin, Mark

2017 Beyond Settler Time: Temporal Sovereignty and Indigenous Self-Determination. Duke University Press, Durham, North Carolina.

Robertson, James Alexander

1993 The Account by a Gentleman from Elvas. In The De Soto Chronicles: The Expedition of Hernando de Soto to North America, 1539-1543, Vol. I, edited by Lawrence A. Clayton, and Vernon James Knight Jr., and Edward C. Moore, pp. 19-219. University of Alabama Press, Tuscaloosa.

Rodning, Christopher B., Robin A. Beck, David G. Moore, and James B. Legg

2016 Spanish Material Culture from the Berry Site. In Fort San Juan and the Limits of Empire: Colonialism and Household Practice at the Berry Site, edited by Robin A. Beck, Christopher B. Rodning, and David G. Moore, pp. 303-340. University Press of Florida, Gainesville.

Sahlins, Marshall

1993 Goodbye to Tristes Tropes: Ethnography in the Context of World History. Journal of Modern History 65:125

Schmader, Matthew

2016 How Tribal Consultation and Non-Invasive Techniques Led to a Better Understanding of Vázquez de Coronado's Expedition of 1540-1542. Advances in Archaeological Practice 4:1-16.

Semerari, Giulia Saltini

2017 Towards an Archaeology of Disentanglement. Journal of Archaeological Method and Theory 24:542-578. Sexton, Jared

2016 The Vel of Slavery: Tracking the Figure of the Unsovereign. Critical Sociology 42:583-497.

Shelby, Charmion

1993 La Florida, by Garcilaso de la Vega, the Inca. In The De Soto Chronicles: The Expedition of Hernando de Soto to North America, 1539-1543, Vol. II, edited by Lawrence A. Clayton, Vernon James Knight Jr., and Edward C. Moore, pp. 25-559. University of Alabama Press, Tuscaloosa.

Sheptak, Russell N., and Rosemary A. Joyce

2019 Hybrid Cultures: The Visibility of the European Invasion of Caribbean Honduras in the Sixteenth Century. In Material Encounters and Indigenous Transformations in the Early Colonial Americas, edited by Corinne L. Hofman, and Floris W. M. Keehnen, pp. 221-237. Brill, Leiden, Netherlands.

Silliman, Stephen W.

2005 Culture Contact or Colonialism? Challenges in the Archaeology of Native North America. American Antiquity 70:55-74.

2013 What, Where, and When Is Hybridity? In The Archaeology of Hybrid Material Culture, edited by Jeb J. Card, pp. 466-500. Center for Archaeological Investigations Occasional Paper No. 39. Southern Illinois University Press, Carbondale.

2015 A Requiem for Hybridity? The Problem with Frankensteins, Purées, and Mules. Journal of Social Archaeology 15:277-298. 
2016 Disentangling the Archaeology of Colonialism and Indigeneity. In Archaeology of Entanglement, edited by Lindsay Der and Francesca Fernandini, pp. 31-48. Routledge, New York.

Smith, Allison M.

2017 Sherds with Style: A Ceramic Analysis from a Protohistoric Site in Oktibbeha County, Mississippi. Master's thesis, Department of Sociology and Anthropology, University of Mississippi, Oxford.

Smith, Marvin T.

1987 Archaeology of Aboriginal Culture Change in the Interior Southeast. University Press of Florida, Gainesville.

Smith, Marvin T., and David J. Hally

2020 The Acquisition of Sixteenth-Century European Objects by Native Americans in the Southeastern United States. In Modeling Entradas: Sixteenth-Century Assemblages in North America, edited by Clay Mathers, pp. 203-246. University of Florida Press, Gainesville.

Smith, Steven D., and James B. Legg

2020 Metal Detecting Surveys at Stark Farms and Environs: Seasons 2018 and 2019. Submitted to Department of Heritage Preservation, Chickasaw Nation. Copies available from University of South Carolina, South Carolina Institute of Archaeology and Anthropology, Columbia.

Sorresso, Domenique C., and Patrick S. Quinn

2020 Re-examining Shell-Tempered Chickasaw Pottery in Post-Contact Mississippi, USA. Journal of Archaeological Science: Reports 32. DOI:10.1016/j.jasrep. 2020.102415.

South, Stanley A., Russell K. Skowronek, and Richard E. Johnson

1988 Santa Elena. Archaeology Series 7. South Carolina Institute for Archaeology and Anthropology, Columbia.

Stahl, Ann Brower

2010 Material Histories. In The Oxford Handbook of Material Culture Studies, edited by Dan Hicks and Mary C. Beaudry, pp. 148-170. Oxford University Press, Oxford.

Stockhammer, Philipp W.

2013 From Hybridity to Entanglement, From Essentialism to Practice. Archaeological Review from Cambridge 28(1):11-28.

Thomas, Joe

2017 Chickasaw Explorers: Linking the Past to Your Present. Istunowa: The Journal of Chickasaw History and Culture 19(1):28-33.

Thomas, Nicholas

1994 Colonialism's Culture: Anthropology, Travel and Government. Princeton University Press, Princeton, New Jersey.

Trabert, Sarah

2018 Reframing the Protohistoric Period and the (Peri)
Colonial Process for the North American Central Plains. World Archaeology 50:820-834.

Trigg, Heather

2020 Spanish-Pueblo Interactions in New Mexico's Seventeenth-Century Spanish Households: Negotiations of Knowledge and Power in Practice. International Journal of Historical Archaeology 24:618-641.

VanValkenburgh, Parker

2013 Hybridity, Creolization, Mestizaje: A Comment. Archaeological Review from Cambridge 28(1):300-322.

Vizenor, Gerald

1999 Manifest Manners: Narratives on Postindian Survivance. University of Nebraska Press, Lincoln.

Voss, Barbara L.

2011 Postcolonial and Queer Perspectives on the Archaeology of Sexuality and Empire. In The Archaeology of Colonialism: Intimate Encounters and Sexual Effects, edited by Barbara L. Voss and Elenor Conlin Casella, pp. 11-28. Cambridge University Press, Cambridge.

Weaver, Jace, Craic S. Womack, and Robert Warrior

2006 American Indian Literary Nationalism. University of New Mexico Press, Albuquerque.

Werbner, Pnina

1997 Introduction: The Dialectics of Cultural Hybridity. In Debating Cultural Hybridity: Multi-Cultural Identities and the Politics of Anti-Racism, edited by Pnina Werbner and Tariq Modood, pp. 1-26. Zed Books, London.

White, Richard

1991 The Middle Ground: Indians, Empires, and Republics in the Great Lakes Region, 1650-1815. Cambridge University Press, Cambridge.

Worth, John A.

1993a Account of the Northern Conquest and Discovery of Hernando de Soto by Rodrigo Rangel. In The De Soto Chronicles: The Expedition of Hernando de Soto to North America, 1539-1543, Vol. 1, edited by Lawrence A. Clayton, Vernon James Knight Jr., and Edward C. Moore, pp. 247-306. University of Alabama Press, Tuscaloosa.

1993b Relation of the Island of Florida by Luys Hernández de Biedma. In The De Soto Chronicles: The Expedition of Hernando de Soto to North America, 1539-1543, Vol. 1, edited by Lawrence A. Clayton, Vernon J. Knight Jr., and Edward C. Moore, pp. 221-246. University of Alabama Press, Tuscaloosa.

Zedeño, Maria N.

2009 Animating by Association: Index Objects and Relational Taxonomies. Cambridge Archaeological Journal 19:407-417.

Submitted September 15, 2020; Revised December 11, 2020;

Accepted December 11, 2020 